\begin{tabular}{|c|c|}
\hline $\begin{array}{l}\text { 2. To: (Receiving Organization) } \\
\text { TWRS Safety Programs }\end{array}$ & $\begin{array}{l}\text { 3. From: (originating Organization) } \\
\text { TWRS Equipment Engineering }\end{array}$ \\
\hline $\begin{array}{l}\text { 5. Proj./Prog./Dept./Div.: } \\
74 F 10\end{array}$ & $\begin{array}{l}\text { 6. Design Authority/ Design Agent/Cog. } \\
\text { Engr.: } \\
\text { J. R. Kriskovich/ } \\
\text { E. M. Veith/ 0. D. Nelson }\end{array}$ \\
\hline $\begin{array}{l}\text { 8. Originator Remarks: } \\
\text { This is the Operational Test } \\
\text { Exhauster. This operationa? } \\
\text { OTP-060-001 (Appendix A) } \\
\text { Distribute per cover sheet. } \\
\text { ETN-96-0018 }\end{array}$ & $\begin{array}{l}\text { port, } 500 \text { CFM Portable } \\
t \text { was done in accordance with }\end{array}$ \\
\hline
\end{tabular}

11. Receiver Remarks: 11A. Design Baseline Document? [] Yes [X] No
4. Related EDT No.:

$\mathrm{N} / \mathrm{A}$

7. Purchase Order No.:

$$
\text { N/A }
$$

9. Equip./Component No.:

$$
\mathrm{N} / \mathrm{A}
$$

10. System/Bldg./Facility:

\section{$200 \mathrm{G}$}

12. Major Assm. Dwg. No.:

H-14-100765, Rev. 0

13. Permit/Permit Application No.: $N / A$

14. Required Response Date: $N / A$

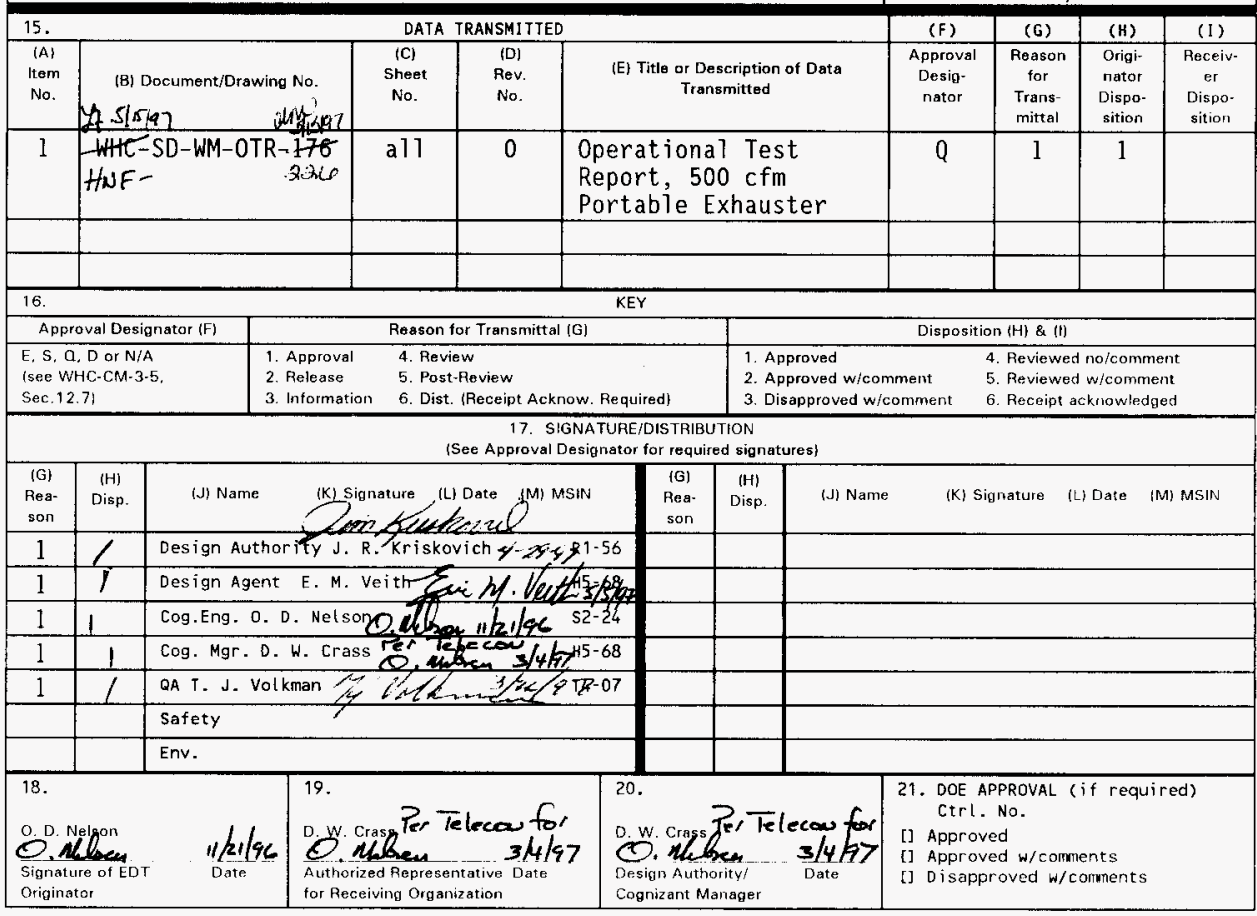

BD-7400-172-2 (05/96) GEF097 


\title{
Operational Test Report, 500 CFM Portable Exhauster
}

\author{
0. D. Nelson
}

Numatec, Richland, WA 99352

U.S. Department of Energy Contract DE-AC06-87RL10930

$$
6013042^{2}
$$

EDT/ECN: 613040 airk $\$ 15 k i 2$

Org Code: $74 \mathrm{~F} 10$

UC: 2030

B\&R Code: $I 213120072$

Charge Code: $N 2053$

Total Pages: 93

Key Words: ventilation, portable exhauster, HEPA filter

Abstract: This is the operational test report for a $500 \mathrm{cfm}$ portable exhauster for use on Tank Farms single shell tanks during saltwell pumping operations.

TRADEMARK DISCLAIMER. Reference herein to any specific comercial product, process, or service by trade name, trademark, manufacturer, or otherwise, does not necessarily constitute or imply its endorsement, recormendation, or favoring by the United States Government or any agency thereof or its contractors or subcontractors.

Printed in the United States of America. To obtain copies of this document, contact: WHC/BCS Document Control Services, P.O. Box 1970, Mailstop H6-08, Richland WA 99352, Phone (509) 372-2420; Fax (509) 376-4989.
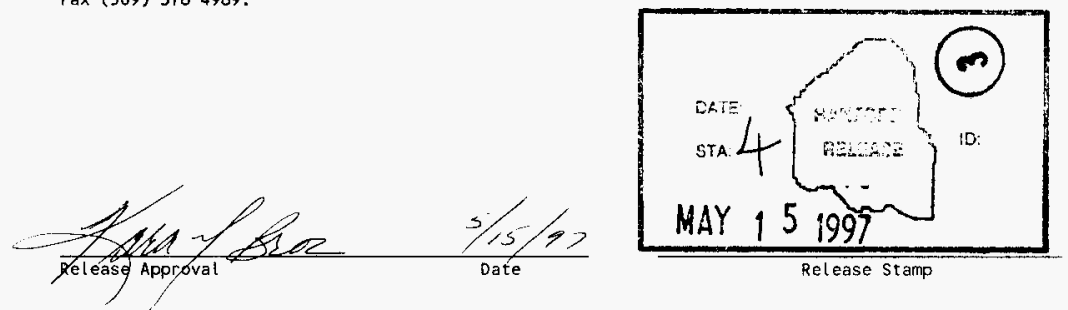

Approved for Public Release 
HNF-

WHE-SD-WM-OTR-226 Revision 0

5) 16197

OPERATIONAL TEST REPORT

FOR

500 CFM PORTABLE EXHAUSTER

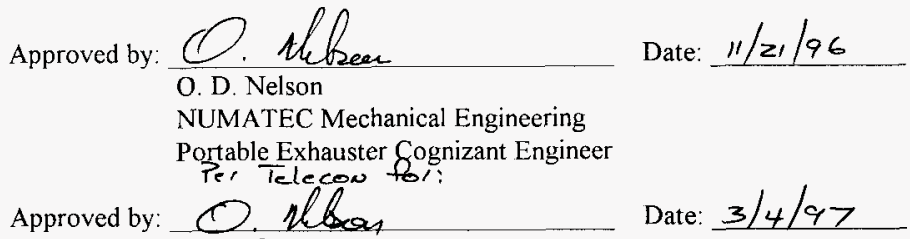

D. W. Crass

Manager Lockheed Mechanical Systems 


$$
\begin{aligned}
& \text { HNF- } \\
& \text { WHE-SD-WM-OTR-226 Revision } 0 \\
& \text { D. } 5.15 .97
\end{aligned}
$$

1.0 INTRODUCTION

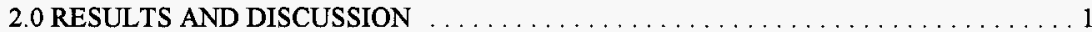

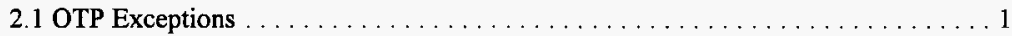

2.1.1 Filter 1 Differential Pressure HI-HI Alarm Acknowledgement . . . . . . 1

2.1.2 Filter 2 Differential Pressure HI-HI Alarm Acknowledgement . . . . . . . 2

2.1.3 Filter 1 \& 2 Differential Pressure HI-HI and LO Alarm Acknowledgement...2

2.1.4 Plenum Differential Under Alarm . . . . . . . . . . . . . . . . . 2

2.1.5 Prefilter Pressure HI $\ldots \ldots \ldots \ldots \ldots \ldots \ldots \ldots \ldots \ldots \ldots$

2.1.6 Stackflow LO Alarm Test $\ldots \ldots \ldots \ldots \ldots \ldots \ldots \ldots \ldots \ldots \ldots$

2.1.7 Glycol Pump/Heater Test $\ldots \ldots \ldots \ldots \ldots \ldots \ldots \ldots \ldots \ldots \ldots \ldots$

2.1 .8 Glycol Heater Test . . . . . . . . . . . . . . . . . . . 3

3.0 SUMMARY AND CONCLUSIONS $\ldots \ldots \ldots \ldots \ldots \ldots \ldots \ldots \ldots \ldots \ldots \ldots$

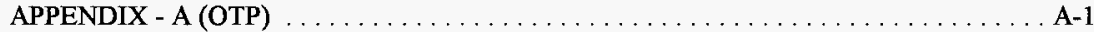




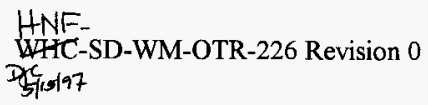

\subsection{INTRODUCTION}

A 500 Cubic foot per minute (CFM) portable exhauster system was fabricated for use on 241-A-101 during saltwell pumping activities. An operational test was performed on this unit during 9/20/96 through 10/14/96 in the 241-A Tank Farm. This operational test was done in accordance with OTP-060-001 Rev 0 (See Appendix A of this report). The test was performed with exceptions.

\subsection{RESULTS AND DISCUSSION}

The $500 \mathrm{cfm}$ portable exhauster was tested by OTP-060-001 Rev 0 with the following exceptions as listed in the Operational Test Procedure (OTP) Exception Log:

1) Filter 1 differential pressure $\mathrm{HI}-\mathrm{HI}$ alarm acknowledgment.

2) Filter 2 differential pressure $\mathrm{HI}-\mathrm{Hl}$ alarm acknowledgment

3) Filter $1 \& 2$ differential pressure HI-HI alarm acknowledgment

4) Plenum differential pressure $H I$.

5) Prefilter pressure HI

6) Stackflow LO alarm test

7) Glycol pump/heater test.

8) Glycol heater test.

\subsection{OTP Exceptions}

The exceptions listed in section 2.0 were taken from the OTP exception log. For each item listed above, a discussion of the impact and resolution is presented in the following sections.

\subsubsection{Filter 1 Differential Pressure HI-HI Alarm Acknowledgment}

When testing HEPA filter 1 differential pressure HI-HI \& LO alarms, a "stack flow under" and a " $<0.0 \mathrm{cfm"} \mathrm{alarms} \mathrm{were} \mathrm{received.} \mathrm{In} \mathrm{addition} \mathrm{a} \mathrm{filter} 1$ differential pressure $\mathrm{HI}$ alarm is received and required acknowledgment as the test pressure is 
brought down from the HI-HI set point.

These were items not present in the OTP and changes were made to the OTP to detail these conditions. All changes were redlined, initialed and dated by the Test Director.

\subsubsection{Filter 2 Differential Pressure HI-HI Alarm Acknowledgment}

When testing HEPA filter 2 differential pressure HI-HI \& LO alarms, a "stack flow under" and a "<0.0 cfm" alarms were received. In addition a filter 2 differential pressure $\mathrm{HI}$ alarm is received and required acknowledgment as the test pressure is brought down from the HI-HI set point.

These were items not present in the OTP and changes were made to the OTP to detail these conditions. All changes were redlined, initialed and dated by the Test Director.

\subsubsection{Filter $1 \& 2$ Differential Pressure HI-HI and LO Alarm Acknowledgment}

When testing HEPA filter 1 \& 2 (overall differential pressure) for alarms associated with differential pressure $\mathrm{HI}-\mathrm{HI}$ and LO, each was accompanied by a "stack flow under" and a " $<0.0 \mathrm{cfm}$ " alarms. In addition, the shutdown of the fan when a pressure signal was inputted for a LO differential pressure took 15 seconds instead of 10 seconds.

These were items not present in the OTP and changes were made to the OTP to detail these conditions. All changes were redlined, initialed and dated by the Test Director. The fan shutdown in the computer program was changed from 15 seconds to 10 seconds and witnessed by the Cognizant Engineer and QC engineer.

\subsubsection{Plenum Differential Under Alarm}

Plenum differential under alarm appears on the alarm message panel when the OTP specified that a plenum pressure LO alarm would appear

This item was incorrect per the OTP and changes were made to the OTP to detail this condition. All changes were redlined, initialed and dated by the Test Director. 


\section{HNF
WHC-SD-WM-OTR-226 Revision 0
Dofis/97}

\subsubsection{Prefilter Pressure HI}

Prefilter pressure $\mathrm{HI}$ alarm message is received while OTP specified a plenum pressure LO.

This item was not correct per the OTP and changes were made to the OTP to detail this condition. All changes were redlined, initialed and dated by the Test Director.

\subsubsection{Stackflow LO Alarm Test}

Inadequate test direction was given to simulate a STACK FLOW LO condition without racing the exhaust fan. The STACKFLOW UNDER is received on acknowledgment of stackflow LO.

Additional direction was added to the OTP. All changes were redlined, initialed and dated by the Test Director.

\subsubsection{Glycol Pump/Heater Test}

Acknowledgment of "GLYCOL PUMP OFF" and "GLYCOL LEVEL LOW" is required during activating power and was not specified in the OTP. Verification that the glycol pump is required and was not specified in the OTP. Additionally, "GLYCOL LEVEL LO" is incorrectly called out as "GLYCOL LO".

These items were not present in the OTP and changes were made to the OTP to detail these conditions. All changes were redlined, initialed and dated by the Test Director.

\subsubsection{Glycol Heater Test}

The OTP omitted turning on breaker \#6 to the ON position and acknowledging various alarms during the initial power up of the glycol heater system. The OTP incorrectly specifies "HEATER TEMP LO" as "AIR TEMPERATURE LO".

These items were not present in the OTP and changes were made to the OTP to detail these conditions. All changes were redlined, initialed and dated by the Test Director. 


$$
\text { HNF. }
$$

W4He-SD-WM-OTR-226 Revision 0

spisige

\subsection{SUMMARY AND CONCLUSIONS}

The $500 \mathrm{cfm}$ portable exhauster had a OTP performed after installation in 241-A Tank Farm. The $500 \mathrm{cfm}$ portable exhauster is part of a hydrogen mitigation system outlined in Safety Assessment For Salt Well Jet Pumping Operations Tank 241-A-101: Hanford Site, Richland, Washington, WHC-SD-WM-SAD-036, Revision O, 1996.

The purpose of the portable exhauster is to;

- enhance mixing of dome vapors;

- reduce flammable gas inventory;

- reduce flammable gas residence time;

- increase tank farm personnel safety.

The $500 \mathrm{cfm}$ portable exhauster was successfully tested and performed as designed. 
HNF

WHC-SD-WM-OTR-226 Revision 0

A-1

Dr.s.97

APPENDIX - A (OTP) 


\section{OPERATIONAL TEST PROCEDURE FOR THE 500 CFM PORTABLE EXHAUSTER}

The original signatures are on file.

\begin{tabular}{|c|c|c|c|}
\hline \multicolumn{2}{|c|}{$\begin{array}{l}\text { PCA Incorporated: } \\
\text { Procedure Signatures for 0TP-060-001. } 0\end{array}$} & \multirow{2}{*}{$\begin{array}{l}\text { NEW } \\
\text { TYPE OF CHANGE } \\
\text { DATE }\end{array}$} & \multirow[t]{2}{*}{$\begin{array}{l}\text { SQ } \\
\text { REVIEW } \\
\text { DESIGNATOR }\end{array}$} \\
\hline POSITION/ORG & DELEGATE & & \\
\hline Sys Engineer & I.D. Kaiser & $9 / 11 / 96$ & \\
\hline 0 & I.E. Brighton & $9 / 10 / 96$ & \\
\hline$\checkmark A$ & I.D. Volkman & $9 / 11 / 96$ & \\
\hline WFT Nuc Safety & L.S. Krogsrud & $9 / 10 / 96$ & \\
\hline Stab Act Man/WTFTP & D.J. Saueressig & $9 / 10 / 96$ & \\
\hline Acceptance Review & B.E. Raymond & $9 / 16 / 96$ & \\
\hline Approval Authority & D.P. Reber & $9 / 16 / 96$ & \\
\hline
\end{tabular}




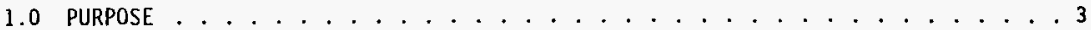

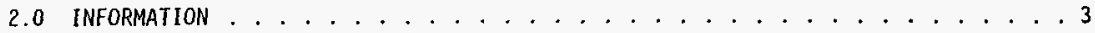

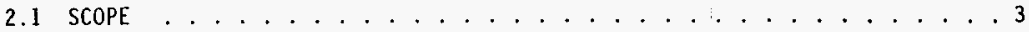

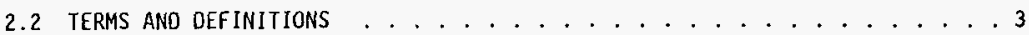

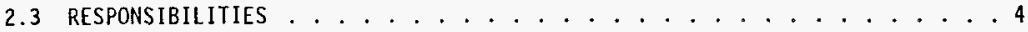

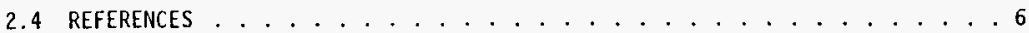

2.5 SAFETY . . . . . . . . . . . . . . . . . . . . . 7

2.6 RADIATION AND CONTAMINATION CONTROL . . . . . . . . . . . 7

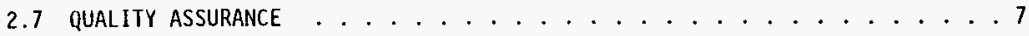

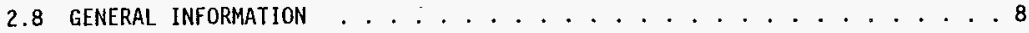

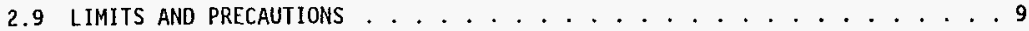

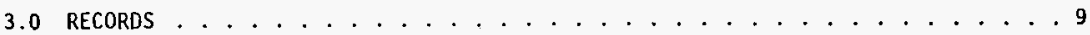

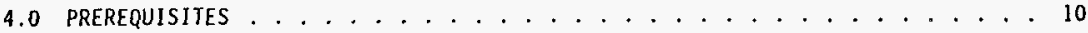

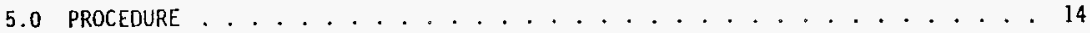

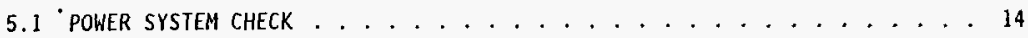

5.2 EXHAUSTER fAN CHECK ........................... 19

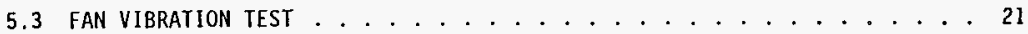

5.4 PRESSURE DECAY TEST. . . . . . . . . . . . . . . . 25

5.5 INTERLOCK/ALARM CHECK. . . . . . . . . . . . . . . . . . . . 34

5.6 SYSTEM ISOLATION . . . . . . . . . . . . . . . . . . . . . . . .

DATA SHEET 1 - LEAKAGE RATE CALCULATION . . . . . . . . . . . . . . 71

DATA SHEET 2 - LEAKAGE RATE CALCULATION ........................... 72

OPERATIONAL TEST PROCEDURE EXCEPTION LOG . . . . . . . . . . . . . . . . . . 73

OPERATIONAL TEST PROCEDURE EXCEPTION RECORD ................. . . . 74

OPERATIONAL TEST PROCEDURE ACCEPTANCE RECORD ................ . . 75

PROCEDURE SIGNATURE HISTORY . . . . . . . . . . . . . . . . . . 76

\begin{tabular}{|c|c|c|}
\hline Document No & Rev/Mod & Page \\
OTP-060-001 & 0 & \\
\hline
\end{tabular}




\section{* PURPOSE}

1.1 There is a concern that flammable gases may exceed the Lower flammability Limit during interim stabilization of identified waste storage tanks. The Portable Exhauster System will be utilized to reduce potential flammable gases that may exist within the dome vapor space of the tank.

1.2 This Operational Test Procedure will test and verify that the Exhauster meets the specified Functional Requirements, Safety requirements, Operations Requirements, and, provide a record of the functional test results. The systems/functions that will be tested are listed in the Scope section that follows.

\subsection{INFORMATION}

\subsection{SCOPE}

NOTE - This Operational Test Procedure will be performed prior to the system being connected to an underground storage tank.

\subsubsection{POWER SYSTEM CHECK}

This check will verify that there is proper electrical power to all the Exhauster systems.

\subsubsection{PRESSURE DECAY TEST}

This will check integrity of the Exhauster train assembly air boundary, including the Seal Pot. The test is designed to address the requirements specified in ASME N510-1989, Testing of Nuclear Air Treatment System,

Section 6.5.3, "Pressure Decay Method".

\subsubsection{INTERLOCK ALARM CHECK}

This check will verify that interlocks perform as required to specific alarm conditions.

\subsubsection{EXHAUSTER FAN CHECK}

This check will verify the exhaust fan and motor rotation.

\subsubsection{FAN VIBRATION CHECK}

This check will verify the fan assembly meets AMSE N509 criteria.

\subsection{TERMS AND DEFINITIONS}
2.2.1 HEPA - High Efficiency Particulate Air
2.2.2 IN W.C. - inches Water Column

Dociunent Ho.

OTP-060-001
Rev/Mod

0

Pago 3 
HNF-

WHC-SD-WM-OTR-226 Revision 0

A-5

D. 5.5 .97

\subsection{RESPONSIBILITIES}

2.3,1 The Maintenance craft personnel are responsible for:

- Provide the test supplies found in step 4.1.

- Providing assistance during the test.

2.3.2 Quality Control (Quality Control) is responsible for:

- Verifying that the procedure sections were performed correctly by witnessing procedure steps as they occur.

2.3.3 Health Physics Technician personnel are responsible for:

- Conducting surveys of all equipment used during this Operational Test Procedure.

- Conducting surveys of all affected areas

0


HNF-

\subsection{RESPONSIBILITIES (Cont.)}

\subsubsection{Test Director}

- Provides concurrence that Operational Test Procedure may commence.

- Ensures the equipment found in step 4.1 of this procedure is available.

- Records equipment status and data per this procedure

- Conducts a pre-job planning meeting.

- Conducts a 241-A-101 Facility and VTP-2212A, Skid A Exhauster walkdown.

- Stop any test which may cause damage to the system until the test procedure has been revised.

- Observe tests, record test data and maintain test log.

- Evaluate recorded data, discrepancies, and exceptions.

- Initiate Procedure Change Authorizations and approve authorized field changes to the Operational Test Procedure.

- Sign and date every procedure section on the working copy as it is completed.

- Record exceptions and test steps that are not performed on the Operational Test Procedure EXCEPTION RECORD. Add additional Operational Test Procedure EXCEPIION RECORD sheets as needed.

- Sequentially log all exceptions on the Operational Test Procedure EXCEPTION LOG. Add additional Operational Test Procedure EXCEPTION LOG sheets as needed.

- Obtain required signatures on the Operational Test Procedure master prior to reproduction and distribution.

\begin{tabular}{|r|r|r|}
\hline Document Ho & Rev/Mod & Page \\
OTP-060-001 & 0 & 5 \\
\hline
\end{tabular}


HNF-

WHE-SD-WM-OTR-226 Revision 0

D.t. 15.97

\section{WORKING COPY}

\subsection{REFERENCES}

2.4.1 The following documents were used to write or are referenced in this procedure:

- WHC-CM-CM-1-10, SAFETY MANUAL, "WKS-6, PRE-JOB SAFETY PLANNING", "WKS-15, ELECTRICAL WORK SAFETY".

- WHC-SD-WM-ATP-176, "ATP FOR 500 CFM PORTABLE EXHAUSTER".

- WHC-CM-6-1 EP 4.2., STANDARD ENGINEERING PRACTICE, "TESTING REQUIREMENTS"

- WHC-IP-1026 APPX M, ENGINEERING PRACTICE GUIOELINES "ACCEPTANCE TEST PROCEDURES AND REPORTS"

- H-14-100737, 500 CFM PORTABLE EXHAUSTER Mechanical drawings

- H-14-100764, ELECTRICAL EXHAUSTER SKID DIAGRAM drawings

- H-14-100765, ELECTRICAL EXHAUSTER SKID PLANS and ELEVATIONS drawings

- H-14-100766, ELECTRICAL EXHAUSTER SKID DETAILS drawings

- 6-TF-155, MAINTENANCE PROCEDURE "AIR FLOW TEST FOR TANK FARM STACKS AND DUCTS", REV. 1, CHG B.

- 6-TF-155-Q, MAINTENANCE PROCEDURE "500 CFM PORTABLE EXHAUSTER AIR FLOW TEST DATA SHEETS", REV. 1, CHG A.

- 6-TF-156, MAINIENANCE PROCEDURE "HEPA FILTER IN-PLACE LEAK teST (AEROSOL TEST)", REV. 0, CHG B.

- 6-TF-156-TU, MaINTENANCE PR0CEDURE "500 CFM PORTABLE EXHAUSTER hePA FILTER AEROSOL TEST DATA SHEETS", REV. 0, CHG 0.

- 6-TF-160, MAINTENANCE PROCEDURE "STATIC BONDING FOR PORTABLE EQUIPMENT IN TANK FARMS", REV. 1, CHG 0.

- vendor information

- WORK PACKAGE, 2E-96-0548

- WORK PACKAGE, 2E-96-0728

\begin{tabular}{|r|r|r|}
\hline $\begin{array}{r}\text { Document Ho. } \\
\text { OTP-060-001 }\end{array}$ & $\begin{array}{r}\text { ReV/Mod } \\
\text { Page }\end{array}$ \\
\hline
\end{tabular}




\subsection{SAFETY}

Warning - Energized circuits and leads are contained inside the cabinets. Observe appropriate electrical precautions. Comply with WHC-CM-1-10, WKS-15, ELECTRICAL WORK SAFETY.

2.5.1 The following administrative procedures control work performed in this procedure:

- Building Emergency Plan, WHC-IP-0263-TF

- Industrial Hygiene Manua\}, WHC-CM-4-40 and WHC-CM-1-11

- Safety Manual, WHC-CM-1-10

- Tank Farm Heaith and Safety Plan (HASP), WHC-SD-WM-HSP-002

\subsection{RADIATION AND CONTAMINATION CONTROL}

2.6.1 Health Physics Technician assistance is required in accordance with Radiation Work Permit.

2.6.2 The following administrative procedures control work performed in this procedure:

- Hanford Site Radiological Control Manual (HSRCM), Rev. 2

- Safety Manual, WHC-CM-1-10

\subsection{QUALITY ASSURANCE}

2.7.1 Ensure that the test(s) are performed per procedure. The Quality Control Inspector shall sign and date each procedure section verifying the data (if any) obtained and that the procedure section has been performed correctly.

Document Ho. OTP-060-001
Rev/Mod

ReviMod

Page 


\subsection{GENERAL INFORMATION}

2.8.1 Complete each procedure step in the given order, unless otherwise noted or as directed by the Test Director.

2.8.2 All entries recorded in this procedure shall be made in black ink.

2.8.3, Editorial changes required to this Operational Test Procedure may be made per the Procedure Change Authorization method by the Test Director and Cognizant Engineer as long as they do not impact operational facility safety function, or performance and will not compromise or influence the test data. Any changes affecting the above stated criteria shall be made in accordance with WHC-CM-6-1, Standard Engineering Practices, EP-2.2, Engineering Document Change Control Requirements.

2.8.4 Do not perform any part of this procedure on faulty equipment. If faulty equipment is discovered, STOP the execution of this procedure and resolve the problem (i.e. repair equipment or write up faulty equipment as an exception and continue).

2.8.5 If the performance of this procedure is suspended for any reason, ensure the requirements of the Lock and Tag System are met before leaving the test site.

2.8.6 At the completion of daily Operational Test Procedure testing, ensure that the VTP-2212A, Skid A Exhauster is shutdown and in a safe condition.

2.8.7 Restore the VTP-2212A, Skid A Exhauster to operating status to continue the Operational Test Procedure.

2.8.8 This procedure DOES NOT contain any separate data/verification sheets. Verification of procedural steps and validity of the data is incorporated into the specific section.

2.8.9 When any unusual hazards are identified, the Job Hazards Analys is form may be used with the Pre-Job Safety Meeting Form as a tool to document the items, needed information and personnel. The Pre-job Safety Meeting Form used with the Job Hazards Analysis will document the meeting. It requires a signature and verification from the Person In Charge of what was covered in the meeting.

Document No. OTP-060-001 Rev/Mod

0
Page 


\subsection{GENERAL INFORMATION (Cont.)}

2.8.10 Any non-conformance of the instrumentation, unexpected results or exceptions during testing shall be sequentially numbered and recorded in the 0perational Test Procedure EXCEPTION LOG. Thus, case-by-case resolution, recording, approval of each exception will be achieved.

2.8.11 Test area of this Operational Test Procedure is the immediate area around the Portable Exhauster that is placed at the 241-A-101 Tank.

\subsection{LIMITS AND PRECAUTIONS}

General Recovery Action - If any Specification Limit in this procedure is violated, immediately notify Shift Manager or Test Director of the condition, unless a specific Recovery Action is stated with the limit.

\subsection{RECORDS}

3.1 The completed working copy of this operational Test procefure and all exception logs and exception records generated by this Operational Test Procedure, will be kept as permanent records and released in an 0perational Test Report.

\begin{tabular}{|c|c|c|}
\hline $\begin{array}{l}\text { Document No. } \\
\text { OTP-060-001 }\end{array}$ & Rev/Mod & Page \\
\hline
\end{tabular}




\section{PREREQUISITES}

4.1 The following supplies shall be available at the work place:

- Pressure Source: minimum range 0 - 15 inches Water Column

Calibration No.817-28-09-004 Expiration Date 7.15.97

- Digital Multi meter: Portable, 0-600 volts ac, $\pm 2 \%$ accuracy.

- Type J Thermocouple Simulator and connection wire $817-13-55-0.14 \quad 10 \cdot 13 \cdot 94$

Calibration No. $817-(3-5 i j-0,2$ Expiration Date 3.16.97

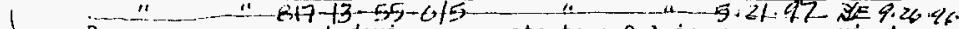

Pressure measurement device, accurate to $\pm 0.1 \mathrm{in}$. wg, approximate range of 0 to $12 \mathrm{in.}$ wg.

Calibration No. $276-3\}-04-139$ Expiration Date $8 \cdot 13.97$

- Barometer, accurate to $\pm 0.01 \mathrm{in}$. Hg, or use Hanford weather station data

- Compressed air source (or blower), pressure reducer (or damper), isolation valve, and safety relief mechanism

- Vacuum source (Capable of producing -12.0 inches Water Column)

- Desktop/Laptop computer to interface with the Exhauster Small Logic Controller 500 program

- Vibration measurement instrument Microlog (CMVAl0)

Calibration No. 752-84-02-001 Expiration Date $11-6-96$

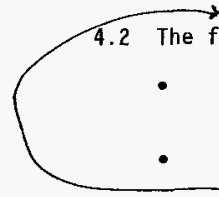

Engineering drawings, maintenance procedures, work packages, and appropriate vendor information listed in section 2.4.

Propylene Glycol Material Safety Data Sheet (\#01552)

TRANSMATION FLEXITESTER 1080 (CUREENT GENERATOR)

CAL.NB.681-13-20-00I CALDLE 10.26 .96 
HNF-

WHC-SD-WM-OTR-226 Revision 0

A-12

$7 \mathrm{~g} \frac{5}{5.15 .17}$

\section{WORKING COPY}

\section{Printed on: sep 19 , 96.11746 , an?}

\section{? PREREQUISITES (Cont.)}

4.3 The following conditions must be met before this test may commence:

4.3.1 A pre-job safety meeting has been held before performing this procedure in accordance with WHC-IP-0842, Vol V Section 4.1, PRE-J08 SAFETY MEETING FORM.

4.3.2 Verify that the Exhauster is ready for testing by walking down the test area, defined by step 2.8.13, to identify and clear all hazardous conditions.

4.3.3 Verify NEC field inspection is complete per the work package 2E-960548.

4.3.4 Verify the Exhauster has been grounded per the work package 2E-96-0548.

4.4 Test Director SHALL VERIFY that section 4.3 is COMPLETE by SIGNING below.

Motal RL

Test Director Signature

$\frac{9-20-96}{\text { Date }}$

4.5 Quality Control Inspector SHALL VERIFY that section 4.3 has been COMPLETED by SIGNING below.

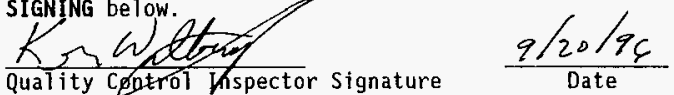

Quality Centrol hispector Signature

Date

\begin{tabular}{|r|r|r|}
\hline Document No, Rev/Mod & Page \\
OTP-060-001 & 0 & 11 \\
\hline
\end{tabular}




\section{ר PREREQUISITES (Cont.)}

NOTE - Quality Control Inspector shall verify current calibration by inspecting calibration stickers on instruments in the field. In the event a sticker is missing or shows a device to be out of calibration, consult the Job Control System Preventative Maintenance/Surveillance system calibration verification.

4.6 Quality Control Inspector shall VERIFY the current calibration and, RECORD the calibration date and calibration due date on the table below.

\begin{tabular}{|c|c|c|c|}
\hline INSTRUMENT & & CALIBRATION DATE & GAUTBRATLN BUE \\
\hline RLEUU PRESSURE XIT) & MPP $P 12213 \mathrm{~A}$ & $9.17-96$ & $9 \cdot 17-97$ \\
\hline $\mathrm{YPP} / \mathrm{HR}=2214 \mathrm{~A} \mathrm{D} / \mathrm{P}$ & $\mathrm{YT}=\mathrm{poI}-2214 \mathrm{~A}$ & $9-17-96$ & $9-17-97$ \\
\hline RRE FILTER FLT $2215 \mathrm{~A}$ DIP. & VTP POI $2215 \mathrm{~A}$ & $9-17-96$ & $9-17-97$ \\
\hline HEPA FILTER ILT=2216A D/P & Vipert $2 \pi 16$ & 9.17 .96 & $9-17-97$ \\
\hline HEPA GITLR GLT $2217 \mathrm{~A}$ D/P & VIP PDI-2217A & $9-17-96$ & $9-17-97$ \\
\hline FIITER TRAIA DIP & $7 T P-P D i-2218 A$ & $9-17-46$ & $9-17 \cdot 97$ \\
\hline EXH STACX rLOH & $4 P+1-2221 \mathrm{~A}$ & $9-18-96$ & $9-18-97$ \\
\hline SEAL pQT IIFVEL & $\mathrm{VIP}=1-2210 \mathrm{~A}$ & $9-18-96$ & $9-18-97$ \\
\hline G. YCOL TANK L EVEI & $\mathrm{rP}-1-2223 \mathrm{~A}$ & $9-18-96$ & $9-18-47$ \\
\hline YENT SKTO INLET IEMP & VIP $T 1-2221 \mathrm{~A}$ & $9 \cdot 23-96$ & 9.23 .97 \\
\hline IST HEPA FILTEP INLET TEYP & TPP.TI $-2222 A$ & $9-23-96$ & $9-23 \cdot 97$ \\
\hline
\end{tabular}

Dociment No.

OTP-060-001

Rev/Mod

0

Page 


\begin{tabular}{|r|r|c|}
\hline$\varepsilon L$ rosed & 0 & $100-090-d 10$ \\
obed & pow/Aey & ON zuaunood \\
\hline
\end{tabular}

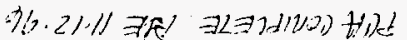

$$
\begin{aligned}
& \text { ifild }
\end{aligned}
$$

- MOLEq ININGIS

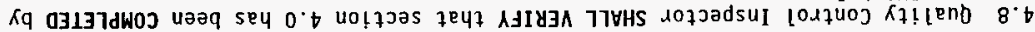

\begin{tabular}{|c|c|c|}
\hline $2+2130$ & $-0.7+3+5$ ou & 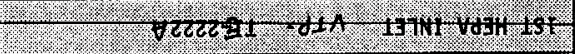 \\
\hline $2+20$ & $-727+500$ & (1) \\
\hline & 174 spest & 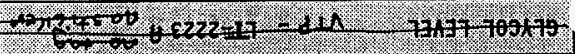 \\
\hline & 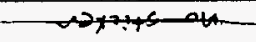 & 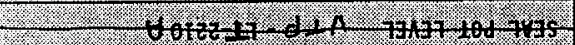 \\
\hline $46-L I-6$ & $n b-(1-6$ & 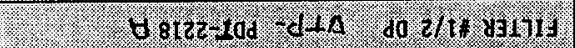 \\
\hline$\angle b-\angle 1-b$ & $9 b-\angle 1-b$ & 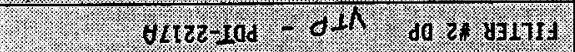 \\
\hline$\angle 6-\angle 1-6$ & $96-L 1-b$ & 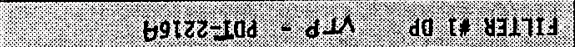 \\
\hline$\angle 6-8 \mid-6$ & $96-81-6$ & 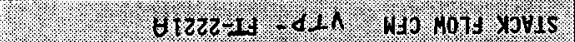 \\
\hline $46-\angle 1-b$ & $9 b-\angle 1-b$ & 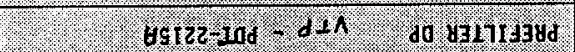 \\
\hline$\angle b-\angle 1-b$ & $a b-\angle 1-b$ & 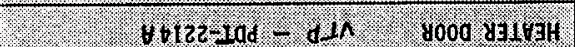 \\
\hline$\angle 6-\angle 1-6$ & $a b-21-6$ & 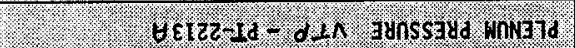 \\
\hline lo gow & aro nowirgrom & anginglsil \\
\hline
\end{tabular}

$$
\begin{aligned}
& \frac{\text { 9180 }}{36 / 610}
\end{aligned}
$$

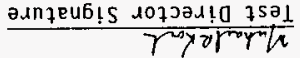

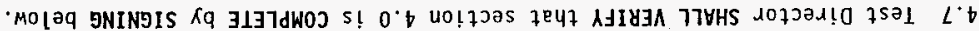

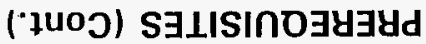




\section{? PROCEDURE}

\subsection{POWER SYSTEM CHECK}

5.1.1 VERIFY panel MCC-Al, disconnect B-2 (A-101 PICS and EXHAUSTER POWER) OFF.

5.1.2 VERIFY Main 480V Disconnect Switch VTP-CKT-2201A is in the OFF position.

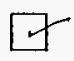

5.1.3 VERIFY Exhauster Fan Motor 480V Disconnect Switch VTP-DS-2212A EXH FAN DR UNIT VFD-2212A PWR is in the OFF position.

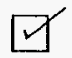

5.1.4 VERIFY Glycol Heater 480V Disconnect Switch VTP-DS-2213A FILTER TRAIN GLY HEATER PWR is in the OFF position.

5.1.5 VERIFY that Mini Power Zone 480V primary Circuit Breaker VTP-CKT-2210A (located in Cabinet VTP-PNL-2204A, DP-2204A MINTPOWER ZONE) is OFF.

5.1.6 VERIFY that Mini Power Zone 240V secondary Circuit Breaker VTP-CKT-2211A (located at Cabinet VTP-PNL-2204A) is OFF.

0


HNF

WC-SD-WM-OTR-226 Revision 0

D. 5.15 .77

\section{WORKING COPY}

\subsection{POWER SYSTEM CHECK (Cont.)}

5.1.7 VERIFY the following $120 \mathrm{~V}$ circuit breakers (located at Cabinet VTP-PNL-2204A) are OFF: ACT. PAR, FANS, HEAT, MESS AGE VIEWS

- Circuit Breaker \# 1 (Enclosure Heaters and Fans)

MoNT.

- Circuit Breaker \#2 (Flammable Gas Monitor)

- Circuit Breaker \#3 (P.L.C.prer)

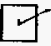

- Circuit Breaker \#4 (Heat Trace)

$$
\text { CONV. RECPP. }
$$

- Circuit Breaker \#5 (Convenience Receptacle)

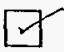

- Circuit Breaker \#6 (PLC control Eit, Module 8)

- Circuit Breaker \#7 (PLC control Eifcuit, Module 9)

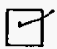

EXH FAN OFF/ENABLE SLL SW

5.1.8 VERIFY Fan-Control Solector Stiteh VTP-HS-2212A (located on door of EXHAUSTER CONTROL CABINET. VTP-PNL-2205A) is in OFF position.

$$
\text { ON/OFF SEL SW } 2210 A
$$

5.1.9 VERIFY Glycol Pump tontol-switch VTP-HS-ZZ13A- (located on door of EXHAUSTER CONTROL CABINET VTP-PNL-2205A) is in OFF position.

0

Page 
HNF-

WIC-SD-WM-OTR-226 Revision 0

Dर 6.15 .97

\section{WORKING COPY}

\subsection{POWER SYSTEM CHECK (Cont.)}

PNL 2205A

FAN

VTP-HS-ZZ13A

5.1.10 VERIFY EAB HEAT/COOL $\mathrm{L}^{\wedge}$ Selector Switetr $\hat{\wedge}$ (located on door of EXHAUSTER CONTROL CABINET VTP-PNL-2205A) is in OFF position.

$$
\text { PNL. } 2206 \mathrm{~A} \quad \text { VTP-HS-2214A }
$$

5.1.11 VERIFY EAB HEAT/COOL. Seleet Switch (located on door of BARRIER INSTRUMENT CABINET VTP-PNL-2206A) is in OFF position.

\section{WARNING}

Energized circuits and leads are contained inside the cabinet. Observe appropriate electrical precautions. Comply with WHC-CM-1-10, WKS-15, ELECTRICAL WORK SAFETY.

5.1.12 POSITION panel MCC-Al, disconnect B-2 (A-101 PICS and EXHAUSTER POWER) to $\mathrm{ON}$.

5.1.13 POSITION Main 480V Disconnect Switch VTP-CKT-2201A 480 VOLT VENT SYSTEM SUPPLY to ON position.

$$
\begin{aligned}
& \text { VTP-DP-2204 } 480 \text { VOLT INPUT BKR } \\
& \text { ZOP-Z2OA ZUTTLO }
\end{aligned}
$$

5.1.14 TURN ON Wint Power Zono 480V primary Circuit-Breaker VTP-CKT-2210A (located at Mini Power Zone Cabinet VTP-PNL-2204A).

$$
\text { DP-2204A 240/120 INPUT BKR }
$$

5.1.15 TURN ON Mini Power Zone 240V socondary ETrcutt Breaker VTP-CKT-2211A (located at Mini Power Zone Cabinet). VTP-PNC-2204A 
HNF.

WHHC-SD-WM-OTR-226 Revision 0

A-18

Dic 5.15 .97

\subsection{POWER SYSTEM CHECK (Cont.)}

5.1.16 POSITION the following l20V circuit breakers (located at Mini Power Zone (abinet) to ON:

- Circuit Breaker \# 1 (Enclosure Heaters and Fans)

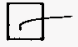

- Circuit Breaker \# 3 (PLC power)

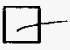

- Circuit Breaker \#4 (Heat Trace)

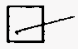

- Circuit Breaker \#5 (Convenience Receptacle)

- Circuit Breaker \#6 (PLC control circuit, Module 8)

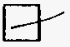

- Circuit Breaker \#7 (PLC control circujt, Module 9)

0


HNF.

\subsection{POWER SYSTEM CHECK (Cont.)}

5.1.17 VERIFY the following indicating lights (located on door of Exhauster Control Cabinet VTP-PNL-2205A) are ILLUMINATED:

- Green FAN OFF light.

- Wilkerson Digital readouts.

- Message View Display VTP-UI-2207A and VTP-UI-2208A (located at Alarm Cabinet VTP-PNL-2207A Swing Out Panel).

Test Director SHALL VERIFY that section 5.1 is COMPLETE by SIGNING below.

Moth h

Test Director Signature

$$
\frac{9 / 23 / 96}{\text { Date }}
$$

5.1.19 Quality Control Inspector SHALL VERIFY that section 5.1 has been COMPLETED by SIGNING below.

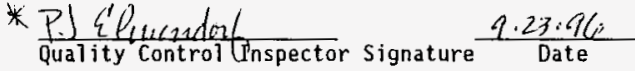

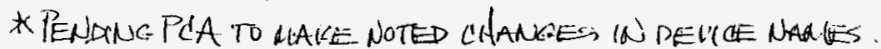
PCA CORLIEIE. PJE $11.12: 96$
Document No.

OTP-060-001
Rev/Mod

0


HNF

W4T-SD-WM-OTR-226 Revision 0

Dof.5.T7

\section{WORKING COPY}

\subsection{EXHAUSTER FAN CHECK}

EXH FAN DR UNIT VFD-Z2.1ZA PWR -
5.2.1 POSITION the(EXHAUSTER FAN MOTOR DISCONNECT SWITCH)VTP-DS-2212A to ON.

5.2.2 VERIFY Fan does NOT start automatically.

5.2.3 VERIFY Green FAN OFF light (located on door of Exhauster Control Cabinet VTP-PNL-2205A) is ILLUMINATED. OFF

5.2.4 VERIFY Red FAN RUNNING 1ight (located on door of Exhauster Control Cabinet VTP-PNL-2205A) is NOT ILLUMINATEO. RUN

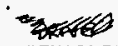

5.2.5 POSITION Fan Control Switch VTP-HS-2212A to "ENABLE" position (located on door of Exhauster Control Cabinet VTP-PNL-2205A).

EXH FAN START

5.2.6 PRESS Fan Start Button (PBSTRT) VTP-PB-2212M AND THEN PRESS Fan Stop Button (PBSTP) VTP-PB-2212H $\mathrm{H}_{\mathrm{E} X \mathrm{~A}} \mathrm{i}_{j}$ e. bump the fan). (located on door of Exhauster Control Cabinet VTP-PNL-2205A).

POSITION Fan Control Switch VTP-HS-2212A to OFF position (located on

5.2.7 POSITION Fan Control Switch VTP-HS-2212A to OFF POS
door of Exhauster Control Cabinet VTP-PNL-2205A).

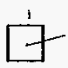

5.2.8 VERIFY that direction of rotation of the Exhauster fan is in the

DIRECIION of the arrow on the fan shaft cover

(or motor shroud).

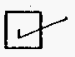

5.2.9 IF direction of rotation of the Exhauster fan is in the CORRECT direction THEN Go ro step 5.2.11.

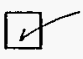




\subsection{EXHAUSTER FAN CHECK (Cont.)}

5.2.10 If direction of rotation of the Exhauster fan is in the incorrect direction, then PERFORM the following:

5.2.10.1 DO NOT EXECUTE any further part of 5.3 in this Operational Test Procedure UNTIL next step through 5.3.8.5

are COMPLETED.

5.2.10.2 POSITION Fan Motor Disconnect Switch VTP-DS-2212A to OFF.

\section{WARNING}

Energized circuits and leads are contained inside the cabinet.

Observe appropriate electrical precautions. Comply with

WHC-CM-1-10, WKS-15, ELECTRICAL WORK SAFETY.

5.2.10.3 CORRECT the Exhauster motor as required per the JCS process.

5.2.10.4 POSITION Fan Motor Disconnect Switch VTP-DS-2212A to ON.

5.2.10.5 REPEAT steps 5.2.6 through 5.2.9.

5.2.11 Test Director SHALL VERIFY that section 5.2 is COMPLETE by SIGNING below.

$\frac{\text { hill Kh }}{\text { Test Director Signature }} \frac{9-23-96}{\text { Date }}$

5.2.12 Quality Control Inspector SHALL VERIFY that section 5.2 is COMPLETE by SIGNING below.

* PJ Ulumendial $\frac{9 \cdot 23.960}{\text { quality control Inspector signature Date }}$

* Pédine chanes as Noted to devile hanes.

PCA CONLIETE. PIE 11.12 .96

\begin{tabular}{|r|r|r|}
\hline Document No. & Rev/Mod & Page \\
OTP-060-001 & 0 & 20 \\
\hline
\end{tabular}


HNF-

\subsection{FAN VIBRATION CHECK}

5.3.1 POSITION Fan Motor Disconnect switch VTP-DS-2212A to OFF.

5.3.2 REMOVE fan shaft guard as required to allow access to the fan shaft bearings.

5.3.3 CONNECT the Jap top CPU to the SLC 500 and FORCE the fan to output to $100 \%$.

5.3.4 POSITION Fan Motor Disconnect switch VTP-DS-2212A to ON.

5.3.5 VERIFY/POSIIION Fan Control Switch VTP-HS-2212A to "ENABLE" position (located on door of Exhauster Control Cabinet VTP-PNL2205A).

5.3.6 PRESS Fan Start Button (PBSTRT) VTP-PB-2212M (located on door of Exhauster Control Cabinet VTP-PNL-2205A)

5.3.7 VERIFY the RED FAN RUNNING light is illuminated on VTP-PNL2205A.

5.3.8 ENSURE Exhaust Fan is operating normally with no unusual noise.

3540

NOTE - Next step starts the Exhauster Fan vibration test. The testing is based on ASME N509 requirements for 3450 RPM (100\% output).

5.3.9 USING the Microlog (CMUA10) vibration instrument, RECORD the measured data in the table at next step.

5.3 .2 .1 OPEN VTP. V-225IA VENT EXHAUST TRAIN OUTLET ISOLATION

5.32 .2 OPEN VTP. V-2250A VENT EXHAUST TRAINI INLGT ISO Document No, OTP-060-001 Rev/Mod

\begin{tabular}{l|l}
\hline & Page \\
1 &
\end{tabular}


HNF-

WHC-SD-WM-OTR-226 Revision 0

A-23

Do.

\subsection{FAN VIBRATION CHECK (Cont.)}

5.3.10 VERIFY that the Filter Bearing Vibration Level on the fan shaft bearings should meet the following criteria:

0 Displacement $<0.6$ MILS (PK-TO PK) at one times the fan speed. $-O R-$

0 Velocity $<0.12$ IN/SEC (PK) at one times the fan speed

\begin{tabular}{|c|c|c|c|c|c|c|}
\hline PLANG & Axial & ok & HORILONIA & bit & VERTICA: : & $0 \mathrm{k}$. \\
\hline 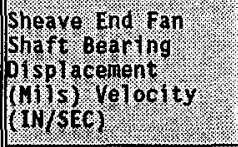 & .014 ips & $r$ & .008 ips & r & .08 ips & $\longleftarrow$ \\
\hline 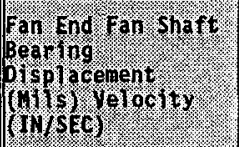 & $.082^{\prime}$ & $r$ & 022 ips & $\sim$ & .108 ips & r \\
\hline
\end{tabular}

5.3.11 USING the vibration instrument, RECORD the measured data in the table at next step.

\begin{tabular}{|r|r|r|}
\hline Document No. & Rev/Mod & Page \\
OTP-060-001 & 1 & 22 \\
\hline
\end{tabular}


HNF.

WHYC-SD-WM-OTR-226 Revision 0

A-24

D广c. 5.97

\subsection{FAN VIBRATION CHECK (Cont.)}

5.3.12 VERIFY that the Overall (unfiltered) Bearing Vibration Levels on the fan shaft bearings meet the following:

0 Displacement $<1.7$ MILS (PK TO PK) Overall.

0 Velocity $<0.31$ IN/SEC (PK) Overall.

\begin{tabular}{|c|c|c|c|c|c|c|c|}
\hline PLANE & 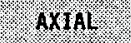 & ok & HOR LONAR: & ox & ?. & VERTISAL. & bx. \\
\hline 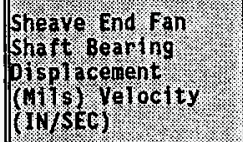 & $.040 \mathrm{ips}$ & $\checkmark$ & 051 ips & & $\sigma$ & 121 ips & - \\
\hline 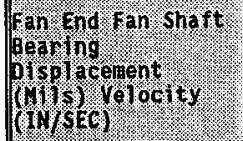 & .120 ips & $r$ & .055 ips & & $r$ & .127 ips & - \\
\hline
\end{tabular}

\begin{tabular}{|r|r|r|}
\hline Document No. & Rev/Mod & \\
OTP-060-001 & 1 & 23 \\
\hline
\end{tabular}


HNF.

WATC-SD-WM-OTR-226 Revision 0

D 5.15 .97

\subsection{FAN VIBRATION CHECK (Cont.)}

5.3.13 VERIFY Exhauster Fan and Motor meet the above requirements.

5.3.13.1 If exhauster meets requirements 60 TO step 5.3.14.

5.3.13.2 If the exhauster Fan Motor fails the above criteria and write an exception and isolate the system as follows:

5.3.13.3 PRESS Fan Stop Button VTP-PB-2212H (10cated on the door of the exhauster control cabinet VTP-PNL-2205A).

5.3.13.4 VERIFY the GREEN FAN STOP light is illuminated on VTP-PNL$2205 \mathrm{~A}$.

5.3.13.5 POSITION Fan Motor Disconnect switch VTP-DS-2212A to OFF.

5.3.13.6 POSITION Fan Control Switch (SSFC) VTP-HS-2212A to "OFF" position (Iocated on door of Exhauster Control Cabinet VIP

PNL-2205A).

5.3.13.7 DISCONNECT the CPU from SLC 500.

5.3.13.8 STOP Operational Test Procedure until exception resolution is accepted.

Document Ho.

Rev/Mod

Pag $\theta$

OTP-060-001

1 
HNF.

W4TC-SD-WM-OTR-226 Revision 0

D.F. 15.97

\subsection{FAN VIBRATION CHECK (COnt.)} 5.3.14 PRESS Fan Stop Button VTP-PB-2212H (lacated on the door of the
exhauster control cabinet VTP-PNL-2205A).

5.3.15 VERIFY the GREEN FAN STOP light is illuminated on VTP-PNL-2205A. OPEN dixonnect VTP-DS.ZZIZA ■

5.3.16 If required, REPLACE fan shaft guard removed to allow access to the fan shaft bearings.

5.3.17 POSITION Fan Control Switch (SSFC) VTP-HS-2212A to "OFF" position (located on door of Exhauster Control Cabinet VTP-PNL2205A).

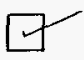

5.3.18 REMOVE force and DISCONNECT CPU from SLC 500.

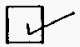

5.3.19 Test Director SHALL VERIFY that section 5.3 is COMPLETE by SIGNING below.

$\frac{2 \mu l}{\text { Test Director Signature }} \quad \frac{9 / 24 / 9 k}{\text { Date }}$

5.3.20 Quality Control Inspector SHALL VERIFY that section 5.3 is COMPLETE by SIGNING below.

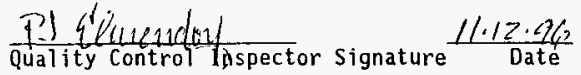

WITJESTED SECTION 9.3 AS RECARDED. WILL SIGN WHEN EXCEPTIONS/PCA CHANBES ARERESOUVED. PJ Elmendr/ 9.24 .96 
HNF.

wHE-SD-WM-OTR-226 Revision 0

Do6.15.97

\subsection{PRESSURE DECAY TEST}

\subsubsection{PERFORM the following inspections:}

5.4.1.1 VERIFY Filter Train ductwork, housings, filters, connections, gaskets, and seals DO NOT have signs of damage, component misalignment, improper installation, or other functional problems. SEE NOTES BELOW

5.4.2 CLOSE Filter train Inlet valve VTP-V-2250A.

note:

- Rubber gaskets on inlet valve are ripped,externat to sealing Surface

- Entire assembly is insulated with insulation in good repair, housings appear square and true.

- Rubber gaskets on discharge valve are compressed but appear to be intact.

- Visual inspection revealed no immediate problems, but insulation makes $100 \%$ verification difficult

$9 / 25 / 96 \quad 8: 37 \quad 29.48$ BARUM. PRESS 
HNF.

WHC-SD-WM-OTR-226 Revision 0

$D f c_{5} .16 .97$

\subsection{PRESSURE DECAY TEST (Cont.)}

5.4.3 CLOSE Filter train Outlet valve VTP-V-2251A.

5.4.4 POSITION the following DP transmitter Manifold Valves:

- "Plenum Pressure Manifold VTP-PT-2213A"

VTP-V-2286A CLOSED

VTP-V-2287A CLOSED

VTP-V-2280A CLOSED

- "Heater D/P Manifold VTP-PDT-2214A" /

VTP-V-2262A CLOSED

VTP-V-2263A CLOSED

VTP-V-2261A CLOSED

- "Pre-Filter D/P Manifold VTP-PDT-2215A" $\checkmark$

VTP-V-2264A CLOSED

VTP-V-2265A CLOSED

VTP-V-2281A CLOSED

- "Filter \#1 D/P Manifold VTP-PDT-2216A"

VTP-V-2266A CLOSED

VTP-V-2267A CLOSED

VTP-V-2282A CLOSED

- "Filter \#2 D/P Manifold VTP-PDT-2217f"

VTP-V-2268A CLOSED

VTP-V-2269A CLOSED

VTP-V-2284A CLOSED

- "Filter \#1/2 D/P Manifold VTP-PDT-2218A" -

VTP-V-2270A CLOSED

VTP-V-2271A CLOSED

VTP-V-2283A CLOSED

- "Stack Flow D/P Manifold VTP-PDT-2221A"

VTP-V-2289A CLOSED

VTP-V-2290A CLOSED

VTP-V-2288A CLOSED

Document No:

1


HNF.

WHHE-SD-WM-OTR-226 Revision 0

D) 6.5 .15 .97

\subsection{PRESSURE DECAY TEST (Cont.)}

5.4.5 VERIFY Seal Pot VTP-SP-2210A is empty by OPENING seal pot drain Valve VTP-V-2259A.

5.4.6 VERIFY Seal Pot Funnel ISO Valve VTP-V-2258A is CLOSED.

5.4.7 VERIFY Seal Pot Overflow Drain Line Valve VTP-V-2260A is CLOSED.

5.4.8 VERIFY/CLOSE Seal Pot Drain Valve VTP-V-2259A.

$y$

5.4.9 VERIFY Fan Drain Line Valve VTP-V-2257A is CLOSED.

5.4.10 UNSCREW Cap on the first stage HEPA Filter Aerosol Injection Port VTP-FTP-2201A on the test section next to Pre-filter.

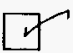

5.4.11 INSTALL AND SEAL the pressure measuring device into the first stage HEPA Filter Aerosol Injection Port VTP-FTP-2201A.

INSTALL the air supply 7 ine (with safety relief mechanism, isolation valve, and pressure reducer) into the second stage HEPA Filter Aerosol Test Port VTP-FTP-2204A.
NOTE - Next step starts checking positive pressure decay.
5.4.13 PRESSURIZE test housing/duct assembly to $+11.5 \pm 0.5$ in $\mathrm{wg}$.

\begin{tabular}{|c|r|r|}
\hline Document No & Pev/Mod & Page \\
OTP-Q60-001 & 1 & 28 \\
\hline
\end{tabular}


HNF:

WHC-SD-WM-OTR-226 Revision 0

D. 5.15 .97

\subsection{PRESSURE DECAY TEST (Cont.)}

5.4.14 LOCATE (using a suitable bubble solution) and SEAL all leaks as practical.

5.4.15 MAINTAIN constant pressure until temperature remains constant within $\pm 0.5^{\circ} \mathrm{F}$ for a minimum of 10 minutes.

5.4.16 ISOLATE the air supply from the filter housing while STARTING the clock.

5.4.17 RECORD the initial time, barometric pressure, pressure, and temperature.

Barometric Pressure 229.42" itg_ Temp: $62.4^{\circ} \mathrm{F}$

Time Taken: 1345

5.4.18 RECORD pressure and temperature readings a minimum of once a minute, UNIIL pressure decays to $75 \%$ of the recorded starting pressure (previous step) or for a maximum of 15 minutes, which ever comes first on the following table.

\begin{tabular}{|c|c|c|c|c|c|c|c|c|}
\hline MUTIE & 80 & 1. & 2 & 3. & 4. & 6 & 6 & 7 \\
\hline 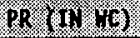 & 12.0 & 11.7 & 11.6 & 11.4 & 11.3 & 11.2 & 11.0 & 11.0 \\
\hline TEN & 62.4 & 62.4 & 62.2 & 62.0 & 62.2 & 62.6 & 62.6 & 62.8 \\
\hline 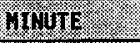 & 8 & 9 & 10 & 11 . & 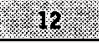 & 13. & 14 & (15: \\
\hline ris $(1) \cdot c$ & 10.8 & 10.7 & 10.6 & 10.5 & 10.3 & 10.3 & 10.1 & 10.0 \\
\hline TELP( $\mathrm{FI}$ & 62.7 & 62.8 & 63.1 & 63.1 & 62.9 & 63.0 & 63.0 & 62.8 \\
\hline
\end{tabular}

\begin{tabular}{|c|c|c|}
\hline Document No. Page \\
OTP-060-001 & Rev/Mod & P \\
\hline
\end{tabular}


HNF.

WHE-SD-WM-OTR-226 Revision 0

D. 5.15 .97

\subsection{PRESSURE DECAY TEST (Cont.)}

5.4.19 RECORD final time, barometric pressure, and temperature. Barometric Pressure $29.42^{\circ} \mathrm{Hg}$ Temp: $62.8^{\circ} \mathrm{F}$ Time Taken: 1400

5.4.20 PERFORM the leak rate calculations per Data Sheet 1.

5.4.21 ENSURE the leak rate calculations are verified independently by Quality Control.

5.4.22 IF $Q<L_{s}$ then RECORD "PASS" on Data Sheet 1. Otherwise, RECORD "RETEST" on Data Sheet 1.

5.4.23 If a retest is needed, THEN PERFORM the following:

5.4.23.1 DETERMINE the leak path(s) and REPAIR leaks as noted on the Exception Resolution.

5.4.23.2 REPEAT steps 5.4.14 through 5.4.24 using new data sheets.

NA

5.4.24 DISCONNECT the air supply.

5.4.25 SLOWLY RELIEVE pressure from Filter Train housing.

5.4.26 CONNECT a vacuum source to the Pressure Test Assembly at Aerosol

\section{Injection Port VTP-FTP-2204A.}

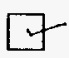

\begin{tabular}{|c|r|r|}
\hline Document No. & Page \\
OTP-O60-001 & 1 & 30 \\
\hline
\end{tabular}




\subsection{PRESSURE DECAY TEST (Cont.)}

NOTE - Next step starts checking negative pressure decay.

5.4.27 DECREASE Filter Train housing internal pressure to -11.5 \pm 0.5 inches Water Column as INDICATED by the Pressure measuring device.

5.4.28 MAINTAIN constant pressure until temperature remains constant within $\pm 0.5^{\circ} \mathrm{F}$ for a minimum of 10 minutes.
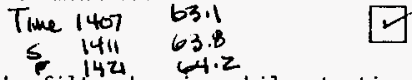

5.4.29 ISOLATE the vacuum source from the filter housing while starting the clock.

5.4.30 RECORD the initial time, barometric pressure, pressure, and temperature on Data Sheet 2.

Barometric Pressure $29.42 \quad$ Temp: 64.3

Time Taken: $\ldots 14.23$

5.4.31 RECORD pressure and temperature readings a minimum of once a minute, UNTIL pressure decays to $75 \%$ of the recorded starting pressure (previous step) or for a maximum of 15 minutes, which ever comes first on the following table.

\begin{tabular}{|c|c|c|c|c|c|c|c|c|}
\hline HINUTE & 0 & 1 & 2 & 3 & 4 & 5 & 6 & 11 \\
\hline $\mathrm{PB}(\mathrm{IN}, \mathrm{VC})$ & -12.0 & -11.8 & -11.6 & -11.3 & $=11.1$ & -11.0 & $=10.8$ & -10.6 \\
\hline TEQP ( F) & 64.3 & 64.3 & 64.5 & 64.9 & 65.2 & 65.4 & 65.6 & 6.5 .5 \\
\hline Minute & 8.8 .8 & 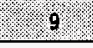 & 10 & 11 & 12.8 & 13. & 14 & 15 \\
\hline 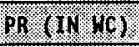 & -10.5 & -10.3 & -10.1 & -9.9 & -9.7 & -9.6 & -9.5 & -9.2 \\
\hline GEP ( F) & $65-3$ & 65,3 & 65.3 & 65.5 & 65.6 & 65.6 & 65.6 & 6.5 .7 \\
\hline
\end{tabular}

\begin{tabular}{|c|c|c|}
\hline $\begin{array}{c}\text { Dociment No. } \\
\text { OTP-060-001 }\end{array}$ & $\begin{array}{r}\text { Rev/Mod } \\
1\end{array}$ & 31 \\
\hline
\end{tabular}




\subsection{PRESSURE DECAY TEST (Cont.)}

5.4.32 RECORD final time, barometric pressure and temperature Barometric Pressure $29.40 \quad$ Temp: 65.7 Time Taken: 1438

5.4.33 PERFORM the leak rate calculations per Data Sheet 2.

5.4.34 ENSURE the leak rate calculations are verified independently by Quality Control.

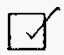

5.4.35 If $Q<L_{s}$ then RECORD "PASS" on Data Sheet 2 AND GO TO step 5.4.37, "0therwise, RECORD "RETEST" on Data Sheet 2.

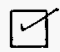

5.4.36 If a retest is needed, then PERFORM the following:

5.4.36.1 DETERMINE the leak path(s) and REPAIR leaks as noted on the Exception Resolution.

5.4.36.2 REPEAT steps 5.4.28 through 5.4.37 using new data sheets.

NA

5.4.37 DISCONNECT the test equipment.

5.4.38 SLOWLY equalize Filter Train housing pressure to atmospheric

5.4.39 REINSTALL the test port plugs VTP-FTP-2201A and VTP-FTP-2204A.

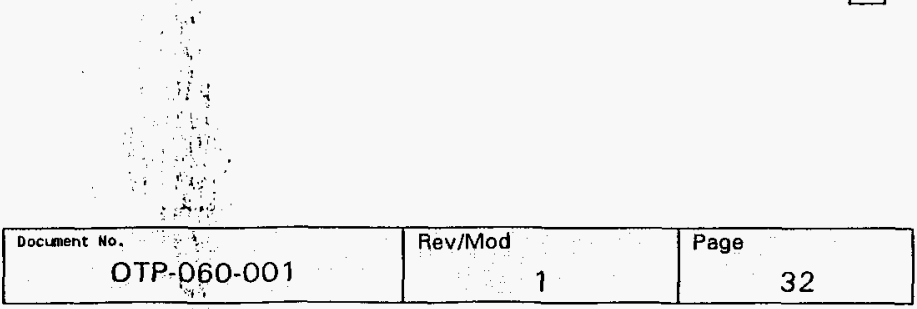




\subsection{PRESSURE DECAY TEST (Cont.)}

5.4.40 OPEN Filter Train Inlet valve VTP-V-2250A.

5.4.41 OPEN Fi7ter Train outlet vaive VIP-V-225]A.

5.4.42 OPEN Fan Drain Line valve VTP-V-2257A.

5.4.43 Position the following DP transmitter Manifold Valves:

- "Plenum Pressure Manifold VTP-PT-2213A"

VTP-V-2286A OPEN

VTP-V-2287A OPEN

VIP-V-2280A CLOSED

$2214 A$

- "Heater D/P Manifold VTP-PDT-Z22t "

VTP-V-2262A OPEN

VTP-V-2253A OPEN

VTP-V-2261A CLOSED

- "Pre-Filter D/P Manifold VTP-PDT-2215A"

VTP-V-2264A OPEN

VTP-V-2265A OPEN

VTP-V-2281A CLOSED

- "Filter \#1 D/P Manifoid VTP-PDT-2216A"

VTP-V-2266A OPEN

VTP-V-2267A OPEN

VTP-V-2282A CLOSED

- "Filter \#2 D/P Manifold VTP-PDT-2217A"

VIP-V-2268A OPEN

VTP-V-2269A OPEN

VTP-V-2284A CLOSED

- "Filter \#1/2 D/P Manjfold VTP-POT-2218A"

VTP-V-2270A OPEN

VTP-V-227IA OPEN

VTP-V-2283A CLOSED

- "Stack Flow D/P Manifold VTP-PDT-2221A"

VTP-V-2289A OPEN

VTP-V-2290A OPEN

VTP-V-2288A CLOSED

\begin{tabular}{|c|c|c|}
\hline Document Ho. & Pev/Mod & Page \\
OTP-060-001 & 1 & 33 \\
\hline
\end{tabular}


HNF-

WAYC-SD-WM-OTR-226 Revision 0

A-35

3.15 .97

\subsection{PRESSURE DECAY TEST (Cont.)}

5.4.44 Test Director SHALL VERIFY that section 5.4 is COMPLETE by SIGNING below.

*hantracl

Test Director Signature

$\frac{10 / 14196}{\text { Date }}$

5.4.45 Quality Control Inspector SHALL VERIFY that section 5.4 is COMPLETE by SIGNING below.

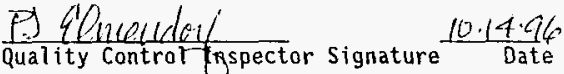

IliTH PCA CHANGES AS NOTED.

PCA COMPLEE, PHE 11.12 .96

1




\subsection{INTERLOCK/ALARM CHECK}

NOTE - During the performance of the Interlock Checks multiple alarms may be displayed. The Test Director may need to reset message view several times to clear the unit alarm.

- The following prerequisites must be met before performing the inter lock checks.

5.5.1 VERIFY VTP-PNL-2205A cabinet temperature on VTP-TI-2211A Control Cabinet Temperature gauge perform the following. $82^{\circ}$

5.5.1.1 IF cabinet temperatures are $>70^{\circ} \mathrm{F}$ VERIFY/REMOVE the winter covers on the Cabinet Fan VIP-F-2205A outlet and Cabinet VTP-PNL-2205A Iniet.

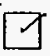

5.5.1.2 IF cabinet temperatures are $>70^{\circ} \mathrm{F}$ POSITION VTP-HS-2213A to teot. sum

5.5.1.3 IF cabinet temperatures are $\leq 40^{\circ} \mathrm{F}$ VERIFY/INSTALL the winter covers on the Cabinet Fan VTP-F-2205A outlet and Cabinet VTP-PNL-2205A Inlet.

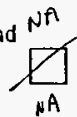

5.5.1.4 If cabinet temperatures are $\leq 40^{\circ} \mathrm{F}$ POSIIION VTP-HS-2213A to HEAT.

5.5.1.5 VERIFY VTP-PNL-2206A cabinet temperature on VTP-TI-2212A Barrier Inst Cabinet Temperature gauge perform the following.

$$
\mathbf{7 3}^{\circ}
$$

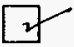

5.5.1.6 IF cabinet temperatures are $>70^{\circ} \mathrm{F}$ POSIIION VTP-HS-2214A to toot. sum

5.5.1.7 If cabinet temperatures are $\leq 40^{\circ} \mathrm{F}$ POSITION VTP-HS-2214A to NA HEAT.

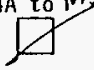

5.5.1.8 VERIFY/OPEN the following butterfly valves:

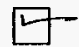

- "VENT EXHaUSt TRAIN INLET ISO" VTP-V-2250A

- "VENT EXHAUST TRAIN OUTLET ISO" VTP-V-225IA 
HNF.

WHC-SD-WM-OTR-226 Revision 0

D. 5.5 .97

\section{WORKING COPY}

\subsection{INTERLOCK/ALARM CHECK (Cont.)}

4:40 $\mathrm{pm}$ 9125196
5.5.1.9 NOTIFY CASS operator that the portable $500 \mathrm{cfm}$ exhauster VTP-2212, Skid A is to be started.

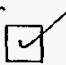

5.5.1.10 VERIFY/POSITION the following valves (located on "VENT SKID SEAL POT" VTP-SP-2210A) are POSITIONS:

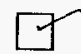

- "SEAL POT DRAIN ISO" VTP-V-2259A CLOSED
- "SEAL POT FUNNEL ISO" VTP-V-2258A CLOSED
"SEAL POT OVERFLOW ISO" VTP-V-2260A OPEN

\subsection{If seal pot level is $\geq 50 \%$ Volume (on VTP-LI- $2210 A)$ go to step 5.5.2.

5.5.1.11 If REQUIRED, FILL the seal pot with water as follows:

5.5.1.12 VERIFY valve seal pot overflow is OPEN VTP-V-2260A.

5.5.1.13 REMOVE fill cover plug for the seal pot reservoir, "VENT SKID SEAL POT" VTP-SP-2210A.

5.5.1.14 OPEN valve, "SEAL POT FUNNEL ISO" VTP-V-2258A.

5.5.1.15 ADD water to the seal pot until VTP-LI-2210A level reads 60 $\%$ of volume.

5.5.1.16 CLOSE the seal pot funnel valve VTP-V-2258A.

5.5.1.17 REPLACE the fill plug for the SEAL POT reservoir VTP-SP-2210A.

5.5.2 VERIFY/POSITION the following valves (located on "GLYCOL HEATER RECIRCULATION SYSTEM " VTP-SP-2223A) POSITIONS:

- "GLY PMP SUCt VALVE " VTP-V-2254a OPEN

- "GLY PMP DISCH VALVE" VTP-V-2255

- "GLY TK HTR OUTLET ISO VLV" VTP-V-2256A OPEN

\begin{tabular}{|c|c|c|}
\hline $\begin{array}{c}\text { Document No } \\
\text { OTP-060-001 }\end{array}$ & Rev/Mod & Page \\
& 1 & 36 \\
\hline
\end{tabular}


HNF.

W4FC-SD-WM-OTR-226 Revision 0

然.15.97

\subsection{INTERLOCK/ALARM CHECK (Cont.)}

$$
6290
$$

5.5.2.1 If seal pot level is $\geq 50 \%$ Volume (on VTP-LI-2223A) as indicated on VTP-LI-2223A Glycol Tank Level go to step 5.5.4.

5.5.3 IF REQUIRED, FILL the GLYCOL EXPANSION TANK VTP-TK-2201A with

$50 \%$ glycol and 50\% water mixture as follows:

5.5.3.1 OPEN fill cover VTP-PRV-2201A for the glycol EXPANSION TANK VTP-TK-2201A.

5.5.3.2 ADD $50 \%$ water and $50 \%$ glycol to the GLYCOL EXPANSION TANK until VTP-LI-2223A GLYCOL TANK LEVEL reads $50 \%$ of Volume

5.5.3.3 CLOSE the fill cover VTP-PRV-2201A for the glycol EXPANSION TANK VTP-TK-2201A.

NOTE - Next step starts check on filter \#l differential pressure transmitter.

5.5.4 CLOSE valves labeled VTP-V-2266A and VTP-2267A on the three valve manifold at HEPA FILTER \#I Transmitter VTP-PDT-2216A (located on top of Filter Train).

5.5.5 REMOVE plug from calibration port on the transmitter VTP-PDT-2216A.

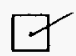

5.5.6 CONNECT a pressure source to calibration port on the transmitter VTP-PDT-2216A.

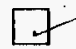

5.5.7 SET pressure source pressure to approximately 3.0 inches Water Column. 
HNF.

WHTC-SD-WM-OTR-226 Revision 0

D马. 5.15 .97

\subsection{INTERLOCK/ALARM CHECK (Cont.)}

Switch HS

5.5.8 POSITION fan Control VTP-PE-2212A to ENABLE position (located on door of exhauster control cabinet VTP-PNL-2205A).

5.5.9 PRESS Fan Start Button VTP-PB-2212M (located on door of Exhauster Control Cabinet VTP-PNL-2205A).

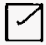

5.5.10 WAIT for the Exhauster fan to come up to speed.

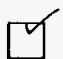

5.5.11 INCREASE pressure source pressure to approximately 4.5 inches Water Column.

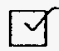

5.5.12 VERIFY the following:

- Rotating Beacon is ILlUMiNATED.

$$
\text { RUN }
$$

- Red fan runNing light is Illuminated.

$$
\text { OFF }
$$

- Green faN OfF light is Not ILLUMinated.

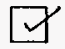

- Wilkerson indicator VTP-PDI-2216A (located on door of Exhauster Control Cabinet VIP-PNL-2205A), corresponding to 3 transmitter VTP-POT-2216A, is READING within a range of 4.5 $( \pm 5 \%$ ) 4.0 inches Water Column and 5.0 inches Water Gauge

- Message View Displays VTP-UI-2207A and VTP-UI-2208A(located at Alarm Cabinet Swing Out Panel) OISPLAY FILTER 1 DP HI. 
HNF-

W4H-SD-WM-OTR-226 Revision 0

DY 5.15 .97

\subsection{INTERLOCK/ALARM CHECK (Cont.)}

5.5.13 ACKNOWLEDGE the alarm by PRESSING the "1" button, then PRESSING the ENTER button three times on the Message View Display (located at Alarm Cabinet VTP-PNL-2207A Swing Out Panel).

5.5.14 VERIFY Rotating Beacon is NOT ILLUMINATED.

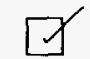

5.5.15 VERIFY Message View Display VTP-UI-2208A (located at Alarm

Cabinet Swing Out Panel) STILL DISPLAYS FILTER 1 DP HI.

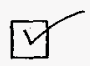

5.5.16 INCREASE pressure source pressure to approximately 5.4 inches Water Gauge.

\subsubsection{VERIFY the following:}

- Exhauster fan has SHUTDOWN.

\section{Rux}

- Red fan RUNNing light is nOt Illuminated.

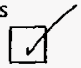

EXERTION $* 1$

Fan

$$
O=F
$$

- Green faN OFF light is Illuminated.

- Rotating Beacon (located on stack supporting framing) is ILLUMINATED.

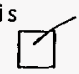

- Wilkerson indicator VTP-PDI-2216A (located on door of Exhauster Control Cabinet VTP-PNL-2205A), corresponding to transmitter VTP-PDT-2216A, is READING within a range of $( \pm 5 \%) 4.5$ inches Water Column and 5.9 inches Water column.

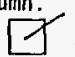

- Message View Display VTP-UI-2207A (located at Alarm Cabinet Swing Out Pane 7 ) DISPLAYS FILTER 1 DP HIHI and FAH SHUTEOHI. STA-

- Differential Pressure Transmitter readout DISPLAYS a value approximately equal to 5.4 inches Water (Column) Gauge.

5.5.18 ACKNOWLEDGE the a] arm by PRESSING the " 1 " button, then PRESSING the ENTER button three times on the Message View Display

(1ocated at Alarm Cabinet VTP-PNL-2207A Swing Out Panel).

verify stackflow under on $\frac{P-2207 A}{A P} \quad \square$ ACILNOWLEDEE STACLFLWW UNDER

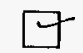

\begin{tabular}{|r|r|r|}
\hline Dociment wo & Rev/Mod & Page \\
OTP_060-001 & 1 & 39 \\
\hline
\end{tabular}


HNF.

WHTC-SD-WM-OTR-226 Revision 0

D्रु 5.15 .97

\subsection{INTERLOCK/ALARM CHECK (Cont.)}

5.5.19 VERIFY Rotating Beacon is NOT ILLUMINATED.

5.5.20 VERIFY Message View Display VTP-UI-2208A (10cated at Alarm Cabinet Swing Out Panel) STILL DISPLAYS FILTER 1 DP HIHI and FAIt SIIFPOHH. STACKFLOW $<0.0$ CFM

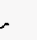

5.5.21 DECREASE pressure source pressure to approximately 3.0 inches Water Column.

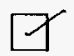

5.5.22 PRESS Fan Start Button VTP-PB-2212M (10cated on door of Exhauster Control Cabinet VTP-PNL-2205A).

GCKNOWLEDE FICTEL I DP HIGH U.

5.5.23 WAIT for the Exhauster fan to come up to speed.

5.5.24 DECREASE pressure source pressure to approximately 0.1 inches Water Column. 


\subsection{INTERLOCK/ALARM CHECK (Cont.)}

5.5.25 VERIFY the following AFTER 10 seconds has passed:

- Exhauster Fan has SHUTDOWN after $10 \mathrm{sec}$.

$$
R \cup N
$$

- Red fan runNing 1 ight is not ILLUMinated.

$$
\text { ofF }
$$

- Green faN OFF light is ILLUMINATEd.
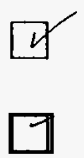

- Rotating Beacon (located on stack supporting framing) is ILLUMINATED.

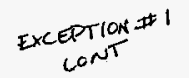

- Wilkerson indicator VTP-PDI-2216A (1ocated on door of Exhauster Control Cabinet VTP-PNL-2205A), corresponding to transmitter VTP-PDT-2216A, is READING within a range of 0.047 inches Water (Column) Gauge and 0.053 inches Water (CoTumn) Gauge.

$$
.08 \text { read }
$$

note: alarm appears on 2zo8A only very briefly.
- Message View Display VTP-UI-2207A and VTP-UI-2208A (located at Alarm Cabinet Swing Out Panel) DISPLAYS FILTER 1 DP LO and-FAA SHTOOHA: $z Z 08$ A - STACTFLOW 0.0

5.5.26 ACKNOWLEDGE the alarm by PRESSING the " 1 " button, then PRESSING the ENTER button three times on the Message View Display (located at Alarm Cabinet VTP-PNL-2207A Swing Out Panel). ACNOWLEDOE STACKFLOW UNDER

\begin{tabular}{|c|c|c|}
\hline $\begin{array}{l}\text { Document No } \\
\text { OTP-060-001 }\end{array}$ & $\begin{array}{r}\text { Rev/Mod } \\
1\end{array}$ & $\begin{array}{r}\text { Page } \\
41\end{array}$ \\
\hline
\end{tabular}

5.5.27 VERIFY Rotating Beacon is NOT ILLUMINATED. 
HNF-

WHE-SD-WM-OTR-226 Revision 0

7. 5.15 .97

\subsection{INTERLOCK/ALARM CHECK (Cont.)}

5.5.28 VERIFY Message View Display VTP-UI-2208A (located at Alarm Cabinet Swing Out Panel) STILL DISPLAYS HIEA-1 OR. LO FAN SHUDOOHN. STACFFLOW $\angle 0.0$ CFM

5.5.29 DISCONNECT pressure source from the transmitter calibration port.

5.5.30 REPLACE plug to calibration port on the transmitter VTP-PDT-2216A.

5.5.31 OPEN valves labeled VTP-V-2266A and VTP-V-2267A on three valve manifold at transmitter VTP-PDT-2216A (located on top of Fi)ter Train).

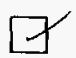

NOTE - Next step starts check on Filter \#2 Differential Pressure Transmitter.

5.5.32 CLOSE valves labeled VTP-V-2268A and VTP-V-2269A on the three valve manifold at HEPA FILTER \#2 Transmitter VTP-PDT-2217A (located on top of filter Train).

5.5.33 REMOVE plug from calibration port on the transmitter VTP-PDT-2217A.
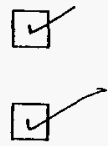

5.5.34 CONNECT a pressure source to calibration port on the transmitter VTP-PDT-2217A.

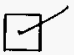

5.5.35 SET pressure source pressure to approximately 2.5 inches Water Column.

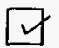

Document No.

Rev/Mod

1

Page 42 
HNF-

WHHC-SD-WM-OTR-226 Revision 0

75.15 .97

\subsection{INTERLOCK/ALARM CHECK (Cont.)}

5.5.36 VERIFY Wilkerson indicator VIP-PDI-2217A (located on door of Exhauster Control Cabinet VTP-PNL-2205A) is READING within a range $( \pm 5 \%)$ of 2.3 inches Water Column and 2.8 inches Water Column.

5.5.37 PRESS Fan Start Button VTP-PB-2212M (1ocated on door of

Exhauster Control Cabinet VTP-PNL-2205A).

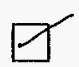

5.5.38 WAIT for the Exhauster fan to come up to speed.

5.5.39 INCREASE pressure source pressure to approximately 3.2 inches Water Column.

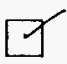

5.5.40 VERIFY the following:

- Rotating Beacon is ILLUMINATED.

RUN

- Red Fan RUNNING light is ILLUMINATED.

OFT

- Green FAN OFF light is NOT ILLUMINATED.

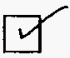

- Wilkerson indicator VTP-PDI-2217A (located on door of Exhauster Control Cabinet VTP-PNL-2205A), corresponding to transmitter VTP-PDT-2217A, is READING within a range of $( \pm 5 \%) 2.90$ inches Water Column and 3.50 inches Water Column.

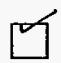

- Message View Displays VTP-UI-2207A and VTP-UI-2208A (located at Alarm Cabinet Swing Out Panel) DISPLAY FILTER 2 DP HI. 


\subsection{INTERLOCK/ALARM CHECK (Cont.)}

5.5.41 ACKNOWLEDGE the alarm by PRESSING the " 1 " button, then PRESSING the ENTER button three times on the Message View Display (located at Alarm Cabinet VTP-PNL-2207A Swing Out Panel).

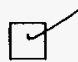

5.5.42 VERIFY Rotating Beacon is NOT ILLUMINATED.

5.5.43 VERIFY Message View Display VTP-UI-2208A (located at Alarm Cabinet Swing out Panel) STILL DISPLAYS FILTER 2 DP HI.

5.5.44 INCREASE pressure source pressure to approximately 3.7 inches Water Column. 


\subsection{INTERLOCK/ALARM CHECK (Cont.)}

5.5.45 VERIFY the following:

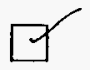

- Exhauster fan has SHUTdown.

$$
\text { RUN }
$$

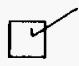

- Red fan RUNNing tight is NOT ILLUMinated.

$$
\text { ofF }
$$

- Green faN Off 1 ight is ILLUninated.

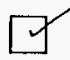
Rotating Beacon (located on stack supporting framing) is
ILLUMINATED.

- Wilkerson indicator VTP-PDI-2217A (located on door of Exhauster Control Cabinet VTP-PNL-2205A), corresponding to transmitter VTP-PDT-2217A, is READING within a range of $( \pm$ $5 \%) 3.40$ inches Water (Column) Gauge and 4.0 inches Water (Column) Gauge.

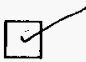

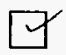 \\ 4 to \\ (}

- Message View Display Vip-UI-220/A (located at Alarm Cabihet Swing Out Panel) DISPLAYS FILTER 2 DP HIHI SHOTDOWH.
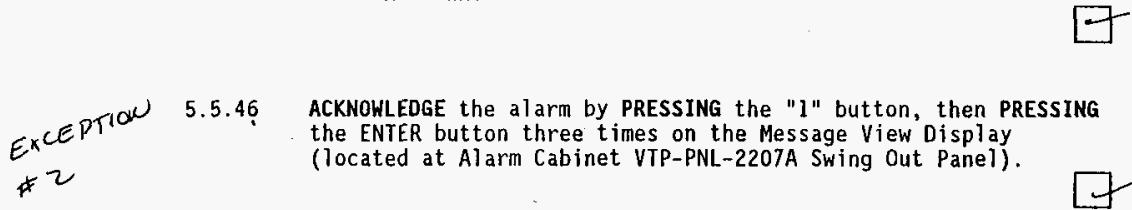

5.5.46 ACKNOWLEDGE the alarm by PRESSING the " $l$ " button, then PRESSING the ENTER button three times on the Message View Display (located at Alarm Cabinet VTP-PNL-2207A Swing Out Panel).

ACKNOWLEDE STAKKIOW UNDER

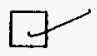

\begin{tabular}{|r|r|r|}
\hline $\begin{array}{r}\text { Decument No } \\
\text { OTP-060-001 }\end{array}$ & Rev/Mod & Page \\
& & 45 \\
\hline
\end{tabular}


HNF -

WHC-SD-WM-OTR-226 Revision 0

28515.97

\subsection{INTERLOCK/ALARM CHECK (Cont.)}

5.5.47 VERIFY Rotating Beacon is NOT ILLUMINATED.

5.5.48 VERIFY Message View Display VTP-UI-2208A (located at Alarm Cabinet Swing Out Panel) STILL DISPLAYS FILTER 2 DP HIHI and-FAN SHWTOWH. STACKFLOW $\angle 0.0$ CFM

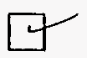

5.5.49 DECREASE pressure source pressure to approximately 2.5 inches Water Column.

AcinowledeE FILTER $=$ DP HIGHE

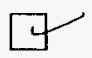

5.5.50 PRESS Fan Start Button VTP-PB-2212M (located on door of Exhauster Control Cabinet VTP-PNL-2205A).

5.5.51 WaIr for the Exhauster fan to come up to speed.

5.5.52 DECREASE pressure source pressure to approximately 0.1 inches

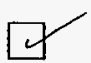

\section{Water Columin.}

1

Page 
HNF.

मु. 5.15 .97

\section{WORKING COPY}

\subsection{INTERLOCK/ALARM CHECK (Cont.)}

\subsubsection{VERIFY the following:}

15
ExCEPTION
$\# 2$ CONT

RUIV

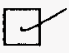

- Red FAN RUNNING light is NOT ILLUMINATED.

$$
O F=
$$

- Green faN Off light is ILLUMINATED.

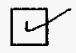

- Rotating Beacon (located on stack supporting framing) is ILLUMINATED.

Wilkerson indicator VTP-PDI-2217A (located on door of
Exhauster Control Cabinet VTP-PNL-2205A), corresponding to
transmitter VTP-PDT-2217A, is READING within a range of Ex CNTH
CoN $( \pm 5 \%) 0.08$ inches Water Column and 0.40 inches Water
Column. .08

- Message View Display VTP-UI-2207A and VTP-UI-2208A (1ocated note: $2208 A$
SHOWS FILTER 2 DP
LO ONCY VEXY BRIERY at Alarm Cabinet Swing Out Panel) DISPLAYS FILTER a DP LO and FAH SHETOOHW.

ACKNOWLEDGE the alarm by PRESSING the " 1 " button, then PRESSING the ENTER button three times on the Message View Display (located at Alarm Cabinet VTP-PNL-2207A Swing Out Panel).

$$
\text { AGLNOWLEDGE STACKFLOW UINDER } 7
$$

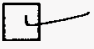


HNF-

WAHC-SD-WM-OTR-226 Revision 0

DS.16.97

\subsection{INTERLOCK/ALARM CHECK (Cont.)}

5.5.55 VERIFY Rotating Beacon is NOT ILLUMIMATED.

5.5.56 VERIFY Message View Display VTP-UI-2208A (located at Alarm Cabinet Swing out Panel) STILL DISPLAYS FItFER- 2 - to-and-FANSHOFOOWH. STACKFLOW $0.0 \mathrm{CFM}$

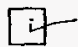

5.5.57 DISCONNECT pressure source from the transmitter calibration port.

5.5.58 REPLACE plug to calibration port on the transmitter

VTP-PDT-2217A.

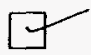

5.5.59 OPEN Valves labeled VTP-V-2268A and VTP-V-2269A on three valve

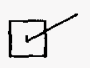 manifold at transmitter VTP-PDT-2217A (located on top of Filter Train).
NOTE - Next step starts check on filter \#1/2 differential pressure transmitter.
5.5.60 CLOSE valves labeled VTP-V-2270A and VTP-V-2271A on the three valve manifold at HEPA FILTER \#1/2 Transmitter VTP-PDT-2218A CLOSE valves labeled VTP-V-2270A
valve manifold at HEPA FILTER \#l/
(located on top of Filter Train).

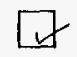

(1) 
HNF.

W4HC-SD-WM-OTR-226 Revision 0

5.15 .97

\subsection{INTERLOCK/ALARM CHECK (Cont.)}

5.5.63 SET pressure source pressure to approximately 3.0 inches Water Column.

5.5.64 VERIFY Wilkerson indicator VTP-PDI-2218A (located on door of

Exhauster Contro) Cabinet VTP-PNL-2205A) is READING within a
range ( $t 5 \%$ ) of 2.5 inches Water (Column) Gauge and 3.50 inche
Water (Column) Gauge.

Exhauster Control Cabinet VTP-PNL-2205A) is READING within a
range ( $t 5 \%$ ) of 2.5 inches Water (Column) Gauge and 3.50 inches
Water (Column) Gauge.

Exhauster Control Cabinet VTP-PNL-2205A) is READING within a
range ( $\pm 5 \%$ ) of 2.5 inches Water (Column) Gauge and 3.50 inche
Water (Column) Gauge.

5.5.65 PRESS Fan Start Button VTP-PB-2212M (located on door of

Exhauster Control Cabinet VTP-PNL-2205A).

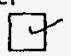

5.5.66 WAIT for the Exhauster fan to come up to speed.

5.5.67 INCREASE pressure source pressure to approximately 4.5 inches Water Column. 4.52

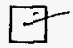

5.5.68 VERIFY the following:

- Rotating Beacon is ILLUMINATED.

RUN

- Red fan RUNning light is Illuminateo.

of $=$

- Green faN OFF light is NOT Illuminated.

- Wilkerson indicator VTP-PDI-2218A (located an door of Exhauster Control Cabinet VTP-PNL-2205A), corresponding to transmitter VTP-PDT-2218A, is READING within a range of ( \pm 5\%) 4.0 inches Water (Column) Gauge and 5.0 inches Water (Column) Gauge.

- Message View Displays VTP-U1-2207A and VTP-UI-2208A (located at Alarm Cabinet Swing Out Panel) DISPLAY FILTER $1 \& 2 \mathrm{DP} \mathrm{HI}$.

5.5.69 ACKNOWLEDGE the alarm by PRESSING the " 1 " button, then PRESSING the ENTER button three times on the Message View Display (located at Alarm Cabinet VTP-PNL-2207A Swing Out Panel).

5.5.70 VERIFY Rotating Beacon is NOT ILLUMINATED.
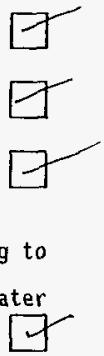
HNF:

WHFC-SD-WM-OTR-226 Revision 0

D怒15.97

\subsection{INTERLOCK/ALARM CHECK (Cont.)}

5.5.71 VERIFY Message View Display VTP-UI-2208A (located at Alarm Cabinet Swing Out Panel) STILL DISPLAYS FILTER 1\&2 DP HI.

5.5.72 INCREASE pressure source pressure to approximately 5.4 inches Water Column. 5.42

5.5.73 VERIFY the following:

- Exhauster Fan has SHUTDOWN.

RUN

- $\quad$ Red FAN RUNNING light is NOT ILLUMINATED.

OF $F$

- Green FAN OFF light is ILLUMINATED.

- Rotating Beacon (located on stack supporting framing) is ILLUMINATED.

- Wilkerson indicator VTP-PDI-2218A (located on door of Exhauster Control Cabinet VTP-PNL-2205A), corresponding to transmitter VTP-POT-2218A, is READING within a range of ( $\pm 5 \%$ ) 4.90 inches Hater (Column) Gauge and 5.90 inches Water (Column) Gauge.

- Message View Display VTP-UI-2207A and VTP-UI-2208A (located at Alarm Cabinet Swing Out Panel) DISPLAY FILTER 182 DP HIHI and FAN SHUTOOWN.

ACKNOWLEDGE the alarm by PRESSING the "1" button, then PRESSING the ENTER button three times on the Message View Display (located at Alarm Cabinet VTP-PNL-2207A Swing Out Panel).

ACKNOWLEDG STACKFLON UNDER G 
HWF:

WATC-SD-WM-OTR-226 Revision 0

S.15.97

\subsection{INTERLOCK/ALARM CHECK (Cont.)}

5.5.75 VERIFY Rotating Beacon is NOT ILLUMINATED.

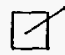

5.5.76 VERIFY Message View Display VTP-UI-2208A (located at Alarm Cabinet Swing out Panel) STILL DISPLAYS FILTER 1 \&2 DP HIHI and FAH SHWTEOWN. STACRROW<0.O CFM

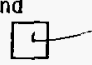

5.5.77 DECREASE pressure source pressure to approximately 3.0 inches Water Column.

ACKWOWLEDE

$$
\text { FICTER I\& OPHIHI }
$$

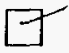

5.5.78 PRESS Fan Start Button VTP-PB-2212M (located on door of Exhauster Control Cabinet VTP-PNL-2205A).

5.5.79 WAIT for the Exhauster fan to come up to speed.
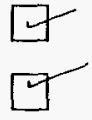

5.5.80 DECREASE pressure source pressure to approximately 0.1 inches Water Column. 
HWF.

D. 5.15 .97

\section{WORKING COPY}

\subsection{INTERLOCK/ALARM CHECK (Cont.)}

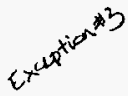

5.5 .81

VERIFY the following:

$$
15
$$

- Exhauster fan has SHUTDOwn after $¥ 0$ sec.

$$
\text { RuN }
$$

- Red fan RUNning light is not illuminated.

$$
\text { OFF }
$$

- Green faN OfF light is Illuminated.
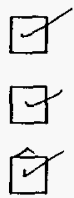

- Rotating Beacon (located on stack supporting framing) is ILLUMINATED .

- Wilkerson indicator VTP-PDI-2218A (located on door of Exhauster Control Cabinet VTP-PNL-2205A), corresponding to transmitter VTP-PDT-2218A, is READING within a range of ( $\pm 5 \%$ ) 0.04 inches Water (Column) Gauge and 0.60 inches Water (Column) Gauge.

$$
\text { .09 }
$$

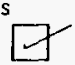

- Message View Display VTP-UI-2207A and VTP-UI-2208A (located

note:

$2208 A$ SES

Iiz DPLO

OWLY MOMENARILY at Alarm Cabinet Swing out Pane1) DISPLAYS FILTER 182 DP L0 aCAAN-SHETDOWH.

ACKNOWLEDGE the alarm by PRESSING the "1" button, then PRESSING the ENTER button three times on the Message View Display (located at Alarm Cabinet VTP-PNL-2207A Swing Out Panel). ACEnOWLEDE STHKFLOW UNDER G

5.5.83 VERIFY Rotating Beacon is NOT ILLUMINATEO.

\begin{tabular}{|r|r|r|}
\hline Pocument No, & Rev/Mod & Page \\
OTP-060-001 & 1 & 52 \\
\hline
\end{tabular}


HWF.

\subsection{INTERLOCK/ALARM CHECK (Cont.)}

5.5.84 VERIFY Message View Display VTP-UI-2208A (10cated at Alarm Cabinet Swing Out Panel) STILL DISPLAYS FHLIER 182 OP LO-aAN SHUTDOHN. STHEKFLOW $<0.0 \mathrm{cFM}$

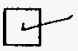

5.5.85 DISCONNECT pressure source from the transmitter calibration port.

5.5.86 REPLACE plug to calibration port on the transmitter

VTP-PDT-2218A.

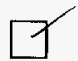

5.5.87 OPEN valves labeled VTP-V-2270A and VTP-V-2271A on three valve manifold at transmitter VTP-PDT-2218A (located on top of Filter Train).

NOTE - Next step starts check on plenum pressure differential pressure transmitter interlock.

5.5.88 CLOSE valves labeled VTP-V-2286A and VTP-V-2287A on the three valve manifold at Plenum Pressure Differential Pressure Transmitter VTP-PT-2213A (located on top of Filter Train).

5.5.89 REMOVE plug from calibration port on the transmitter VTP-PT-2213A.

5.5.90 CONNECT a pressure source to calibration port on the transmitter VTP-PT-2213A.

5.5.91 SET pressure source pressure to 2.5 inches Water Column.

5.5.92 PRESS Fan Start Button VTP-PB-2212M (located on door of Exhauster Control Cabinet VTP-PNL-2205A).
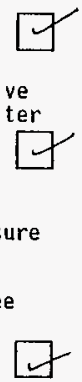
HWF.

\subsection{INTERLOCK/ALARM CHECK (Cont.)}

5.5.93 WAIT for the Exhauster fan to come up to speed.

5.5.94 INCREASE pressure source pressure to 3.5 inches Water Column.

5.5.95 VERIFY the following:

- Exhauster fan has SHUTDOWN.

$$
\text { QUN }
$$

- Red fan RUNNINg light is not Illuminated.

- Green fan OFF light is illuminated.
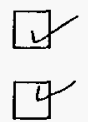

- Rotating Beacon (located on stack supporting framing) is ILLUMINATED.

- Wilkerson indicator VTP-PDI-2213A (located on door of Exhauster Control Cabinet VTP-PNL-2205A), corresponding to transmitter VTP-PT-2213A, is READING within a range ( $\pm 5 \%$ ) of 3.00 inches Water (Column) Gauge and 4.00 inches Water (Column) Gauge.

$$
2208 \mathrm{~A}
$$

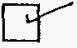

- Message View Display VTP-UI-2207A (7ocated at Alarm Cabinet Swing Out Panel) DISPLAYS PLENUM PRESSURE HI and fANSHEFPOHA.

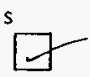


HNF-

WHC-SD-WM-OTR-226 Revision 0

T.15.97

\subsection{INTERLOCK/ALARM CHECK (Cont.)}

5.5.96 ACKNOWLEOGE the alarm by PRESSING the " 1 " button, then PRESSING the ENTER button three times on the Message View Display (located at Alarm Cabinet VTP-PNL-2207A Swing Out Panel). ACKNOWLEDGE STACKFLOW UNPEK

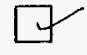

5.5.97 VERIFY Rotating Beacon is NOT ILLUMINATED.

5.5.98 VERIFY Message View Display VTP-UI-2208A (located at Alarm Cabinet Swing Out Panel) STILL DISPLAYS"PLENUM PRESSURE HI and FAH SHUTDOWI. STAC KF LOW $<0.0 \mathrm{cFM}$
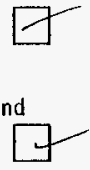

5.5.99 DECREASE pressure source pressure to approximately 1.5 inches Water Column.

5.5.100 PRESS Fan Start Button PB-2212M (located on door of Exhauster Control Cabinet VTP-PNL-2205A).

5.5.101 WAIT for the Exhauster fan to come up to speed.

5.5.102 DECREASE pressure source pressure to -0.1 inches Water Colum Document Mo. 
HNF.

WHE-SD-WM-OTR-226 Revision 0

P.j5. 15.97

\subsection{INTERLOCK/ALARM CHECK (CONt.)}

5.5.103 VERIFY the following AFFER 10-seconds-has-passed:

- Rotating Beacon (located on stack supporting framing) is ILLUMINATED .

- Wi]kerson indicator VTP-PI-2213A (10cated on door of

Exhauster Control Cabinet VTP-PNL-2205A), corresponding to transmitter VTP-PT-2213A, is READING approximately -0.1 inches Water Column.

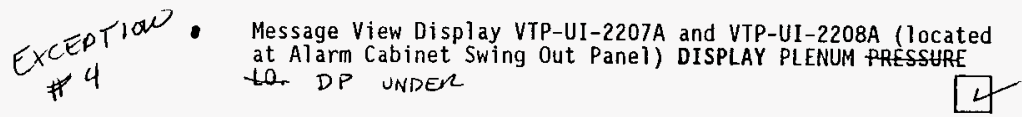

5.5.104 ACKNOWLEDGE the alarm by PRESSING the " 1 " button, then PRESSING the ENTER button three times on the Message View Display (located at Alarm Cabinet VTP-PNL-2207A Swing Out Panel).

5.5.105 VERIFY Rotating Beacon is NOT ILLUMINATED.

5.5.106 VERIFY Message View Display VTP-UI-2208A (located at Alarm Cabinet Swing out Panel) STILL DISPLAYS PLENUM PRESSURE to. DP UNDER
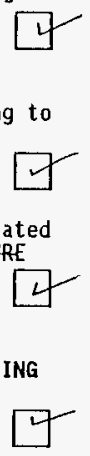

$D_{P R C^{\circ S N e}}$

5.5.107 DISCONNECT pressure source from the transmitter calibration port.
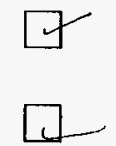

Document No.

OTP-060-001

Rev/Mod

Page 
HNF.

WHC-SD-WM-OTR-226 Revision 0

D\&C. 15.97

\subsection{INTERLOCK/ALARM CHECK (Cont.)}

5.5.108 REPLACE plug to calibration port on the transmitter VTP-PT-2213A.

5.5.109 OPEN valves 1 abeled VTP-V-2286A and VTP-V-2287A on three valve manifold at transmitter VTP-PI-2213A (located on top of Filter Train).

NOTE - Next step starts check on pre-filter Differential Pressure Transmitter alarm.

5.5.110 CLOSE valves labeled VTP-V-2264A and VTP-V-2265A on the three valve manifold at Pre-filter Differential Pressure Transmitter VTP-PDT-2215A (located on top of Filter Irain).

5.5.111 REMOVE plug from calibration port on the transmitter VTP-PDT-2215A.

5.5.112 CONNECT a pressure source to calibration port on the transmitter VTP-PDT-2215A.

5.5.113 SET pressure source pressure to 0.5 inches Water Column.

5.5.114 PRESS fan Start Button VTP-PB-2212M (located on door of Exhauster Control Cabinet VIP-PNL-2205A).

5.5.115 WAIT for the Exhauster fan to come up to speed.

5.5 .116 INCREASE pressure source pressure to 1.0 inches Water Column. 
ANF.

WHE-SD-WM-OTR-226 Revision 0

D. 5.15 .97

\section{WORKING COPY}

\subsection{INTERLOCK/ALARM CHECK (Cont.)}

\subsubsection{VERIFY the following:}

- Rotating Beacon is IlLUMINATED.

$$
\text { RVN }
$$

- Red FAN RUNNING light is ILLUMINATED.

$$
\text { OFF }
$$

- Green faN OFF light is NOT ILLUMinated.

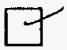

- Wilkerson indicator VTP-POI-2215A (located on door of Exhauster Control Cabinet VTP-PNL-2205A), corresponding to transmitter VTP-PDT-2215A, is READING within a range of 0.90 inches Water Column and 1.10 inches Water Column.

- Message View Display VTP-UI-2207A (located at Alarm Cabinet Swing Out Panel) DISPLAYS PREAFILTER DP HI.

$$
\text { PRESS }
$$
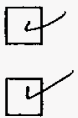

5.5.118 ACKNOWLEDGE the alarm by PRESSING the " 1 " button, then PRESSING the ENTER button three times on the Message View Display (located at Alarm Cabinet VTP-PNL-2207A Swing Out Panel).

\subsubsection{VERIFY Rotating Beacon is NOT ILLUMINATED.}
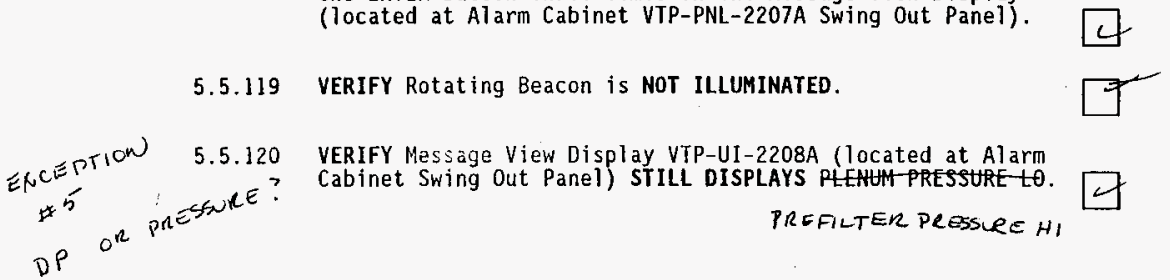
VERIFY Message View Display VTP-UI-2208A (located at Alarm Cabinet Swing Out Panel) STILL DISPLAYS PLEHUM PRESSURE- $t 0$.

$$
\begin{aligned}
& \text { SHIVDOWN EXHAUSTER H } \\
& \text { BY PRESSINE VTP. PB- } 2212 \text { HA }
\end{aligned}
$$

1




\subsection{INTERLOCK/ALARM CHECK (Cont.)}

5.5.121 DISCONNECT pressure source from the transmitter calibration port.

5.5.122 REPLACE plug to calibration port on the transmitter VTP-PDT-2215A.

5.5.123 OPEN valves labeled VTP-V-2264A and VTP-V-2265A on three valve manifold at transmitter VTP-PDT-2215A (located on top of Filter Train).

NOTE - Next step starts testing of stack flow Differential Pressure Transmitter.

5.5.124 CLOSE valves labeled VTP-V-2289A and VTP-V-2290A on the three valve manifold at Stack Flow Differential Pressure Transmitter VTP-FT-2221A (located next to Stack).

5.5.125 REMOVE plug from calibration port on the transmitter. VTP-FT-2221A.

5.5.126 CONNECT a pressure source to calibration port on the transmitter VTP-FT-2221A.

5.5.127 SET pressure source pressure to 0.36 inches Water (Column) Gauge (this corresponds to a flow of 391 CFM).
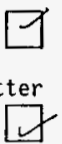 Exhauster Control (abinet VTP-PNL-2205A) is READING within a range of $481 \mathrm{CFM}$ and $401 \mathrm{CFM}$.

5.5.128 VERIFY Wilkerson indicator VTP-PDI-2221A(located on door of

381

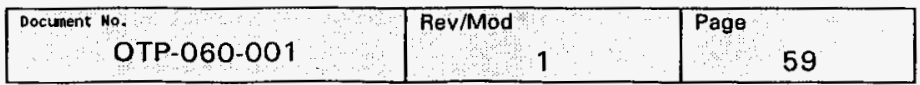




\subsection{INTERLOCK/ALARM CHECK (Cont.)}

5.5.129 INCREASE pressure source pressure to 0.62 inches Water (Column) Gauge (this corresponds to a flow of 530 CFM).

5.5.130 VERIFY the following:

- Rotating Beacon (located on stack supporting framing) is ILLUMINATED.

- Wilkerson indicator (VTP-PDI-2221A) (located on door of Exhauster Control Cabinet VTP-PNL-2205A), corresponding to transmitter VTP-FT-2221, is READING a flow rate within a range of 520 CFM and 540 CFM.

- Message View Display VTP-UI-2207A and VTP-UI-2208A (1ocated at Alarm Cabinet Swing Out Panel) DISPLAY STACK FLOW HI.

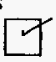

5.5.131 ACKNOWLEDGE the alarm by PRESSING the " 1 " button, then PRESSING the ENTER button three times on the Message View Display (located at Alarm Cabinet VTP-PNL-2207A Swing Out Panel).

\subsubsection{VERIFY Rotation Beacon is NOT ILLUMINATED.}

5.5.133 VERIFY Message View Display VTP-UI-2207A (located at Alarm Cabinet Swing Out Panel) CLEARS alarm message.

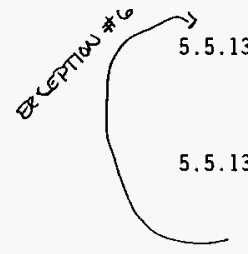

DECREASE pressure source pressure to 0.60 inches Water (Column) Gauge (this corresponds to a flow of 500 (FM). 52,2
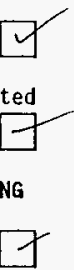
WnF-

W4F-SD-WM-OTR-226 Revision 0

Dr $515 / 97$

\subsection{INTERLOCK/ALARM CHECK (Cont.)}

5.5.136 VERIFY the following AFTER 10 seconds has passed:

- Rotating Beacon (located on stack supporting framing) is ILLUMINATED.

- Wilkerson indicator VTP-PDI-2221A(located on door of Exhauster Control Cabinet VTP-PNL-2205A), corresponding to transmitter VTP-FT-2221A, is READING a flow rate within a range of $220 \mathrm{CFM}$ and $240 \mathrm{CFM} .252$

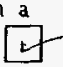

- Message View Display VTP-UI-2207A and VTP-UI-2208A (located at Alarm Cabinet Swing Out Panel) DISPLAY STACK FLOW LO.

- After 20 seconds the fan has shutdown

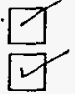

5.5.137 ACKNOWLEDGE the alarm by PRESSING the "1" button, then PRESSING the ENTER button three times on the Message View Display (located at Alarm Cabinet VTP-PNL-2207A Swing Out Panel). ACKNOWLEDSE STKEKFLOW UNDER B

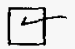

5.5.138 VERIFY Rotating Beacon is NOT ILLUMINATED.

5.5.139 VERIfY Message Vjew Display VTP-UI-2207A (located at Alarm

Cabinet Swing Out Panel) CLEARS alarm message.

5.5.140 DISCONNECT pressure source from the transmitter.

5.5.141 REPLACE plug to the calibration port.
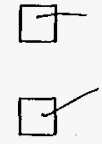

5.5.142 OPEN valves labeled VTP-V-2289A and VTP-V-2290A on three valve manifold at the stack flow differential pressure transmitter VTP-FT-2221A.

$$
\text { PLACE BCAK IN AUTO }
$$




\subsection{INTERLOCK/ALARM CHECK (Cont.)}

NOTE - This section tests the 1st HEPA Filter High Temperature shutdown.

5.5.143 POSITION Circuit Breaker \#6 (located at Mini Power Zone Cabinet VTP-PNL-2204A) to OFF.

5.5.144 DISCONNECT Glycol Liquid Level Transmitter VTP-LT-2223A, 24 VDC, 4-20 mA signal wires and connect $\mathrm{mA}$ simulator. To sianal wires

5.5.145 INPUT 16 Ma through the simulator.

5.5.146 POSITION Circuit Breaker \#6 (located at Mini Power Zone Cabinet VTP-HS-2204A) to ON.

ACKNOWLEDSE GLYCOL PUMP OFF AND GYCOL LEUELLW ON VTP-UI-2IOTA YSPLA (GEE NOTE in Secton 5.5 )

5.5.147 POSITION Giycol Pump Control Switch VTP-HS-2210A to ON (located on door of Exhauster Control Cabinet VTP-PNL-2205A).

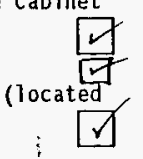

5.5.148 VERIFY the Glycol Heater has STARTED by USING viewing the Glycol Heater Contactor VTP-CON-2213A(located inside Control Cabinet VTP-PNL-2205A): VERIFY The elycolCirculntion Rump VTP-S-2210A has STAKTED

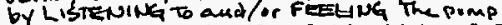

5.5.149 SLOWLY REDUCE the Glycol Liquid Level Transmitter VTP-LT-2223A signal to $12 \mathrm{Ma}$ through the simulator. signal to 12 Ma through the simulator.

VERIFY Glycol Heater has SHUTDOWN by viewing the Glycol Heater Contactor (located at Control Cabinet VTP-PNL-2205A):

5.5.151 VERIFY the Glycol Circulation Pump VTP-S-2210A has SHUTOOWN by LISTENING to and/or FEELING the pump. 
HNF.

WHHe-SD-WM-OTR-226 Revision 0

o. 15.97

\subsection{INTERLOCK/ALARM CHECK (Cont.)}

5.5.152 VERIFY Rotating Beacon (located on stack supporting framing) ILLUMINATED.

$V T P-11-2223 A$

5.5 .153 VERIFY Wilkerson indicator 4 P-FF-2221Allocated on door of Exhauster Control(Cabinet VTP-PNL-2205A), corresponding to transmitter VTP-L $2223 \mathrm{~A}$ (Level Indicator), is READING a liquid

level of $50 \%$ Volume. $51 \%$ Volume Actual

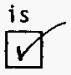

5.5.154 VERIFY Message View Display VTP-UI-2207A and VTP-UI-2208A (located at Alarm Cabinet Swing Out Panel) DISPLAY GLYCOL LO LEVEL

5.5.155 ACKNOWLEDGE the alarm by PRESSING the "l" button, then three times ENTER button on the Message View Display (located at Alarm Cabinet VTP-PNL-2207A Swing Out Panel).

5.5.156 VERIFY Rotation Beacon is NOT ILLUMINATED.

5.5.157 VERIfY Message View Display VTP-UI-2207A (Jocated at Alarm Cabinet Swing out Panel) CLEARS alarm message.

5.5.158 PosIrIon Circuit Breaker \#6 (located at Mini Power Zone Cabinet VTP-PNL-2204A) to OFF.

5.5.159 RECONNECT Giycol Liquid Level Transmitter VTP-LT-2223A, 24 VDC, 4-20 Ma signal wires and disconnect Ma simulator.

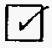

5.5.160 POSITION Circuit Breaker \#3 (located at Mini Power Zone Cabinet VTP-PNL-2204A) to OFF. 
HNF-

WHE-SD-WM-OTR-226 Revision 0

gt5.15.47

\subsection{INTERLOCK/ALARM CHECK (Cont.)}

5.5.161 CONNECT Thermocouple Simulator to the terminals wires located in thermowell junction VTP-TE-2222A.

5.5.162 SET Thermocouple Simulator to $120^{\circ} \mathrm{F}$.

Posmion Circuir Brenker \#6 (VTP-PNLL-2204A PANL) To ON.

5.5.163 POSITION Circuit Breaker \#3 (located at Mini Power Zone Cabinet VTP-PNL-2204A) to ON.

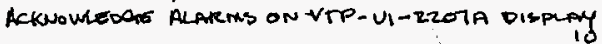

5.5.164 POSITION G1 ycol Pump Control Switch VTP-HS-220TA to ON (1ocated on door of Exhauster Control Cabinet VTP-PNL-2205A).

5.5.165 VERIFY the Glycol Heater has STARTED by viewing the Glycol Heater Contactor VTP-CON-2213ᄉ (located in Control Cabinet VTPPNL-2205A):

5.5.166 VERIFY Wilkerson indicator VTP-TI-2222A(located on door of Exhauster Control Cabinet VIP-PNL-2205A) is READING $120^{\circ} \mathrm{F}$. $110^{\circ} \mathrm{F}$ 
HNF

WHFe-SD-WM-OTR-226 Revision 0

D.5.1597

\section{WORKING COPY}

\subsection{INTERLOCK/ALARM CHECK (Cont.)}

5.5.169 VERIFY the following:

- Rotating Beacon (located on stack supporting framing) is IL.LUNINATED.

- Wilkerson indicator VTP-TI-2222A (located on door of Exhauster Control Cabinet VTP-PNL-2205A) corresponding to VTP-TE-2222A, is READING $200^{\circ} \mathrm{F}$.

- Message View Display VTP-UI-2207A and VTP-UI-2208A (located at Alarm (abinet Swing Out Pane]) DISPLAY HEATER AIR TEMPERATURE HI.

5.5.170 ACKNOWLEDGE the alarm by PRESSING the " 1 " button, then three

5.5.170.1 VERIFY Rotation Beacon is NOT ILLUMINATED.

5.5.170.2 Message View Display VTP-UI-2207A (located at Alarm Cabinet Swing Out Panel) CLEARS alarm message.

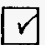

\section{times ENTER button on the Message View Display (located at Alarm Cabinet VTP-PNL-2207A Swing Out Panel).}

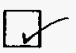

5.5.171 SET Thermocouple Simulator to $40^{\circ} \mathrm{F}$.

5.5.172 VERIFY the Glycol Heater has STARTED by VIEWING the Glycol Heater Contactor (located at Control Cabinet VIP-PNL-2205A): 
HNF.

WHC-SD-WM-OTR-226 Revision 0

都 5.15 .97

\subsection{INTERLOCK/ALARM CHECK (Cont.)}

5.5.173 VERIFY the following:

- Rotating Beacon (located on stack supporting framing) is ILLUMINATED.

- Wilkerson indicator VTP-TI-2222A (located on door of Exhauster Control Cabinet VTP-PNL-2205A) corresponding to VTP-TE-2222A, is READING $40^{\circ} \mathrm{F}$.

- Message View Display VTP-UI 2207A and VTP-UI-2208A (located at Alarm Cabinet Swing Out Panel) DISPLAYS AfR TEMPPE 10.

5.5.174 ACKNOWLEOGE the a] arm by PRESSING the " 1 " button, then three times ENTER button on the Message View Display (located at Alarm Cabinet VTP-PNL-2207A Swing Out Panel).

\subsubsection{VERIFY Rotation Beacon is NOT ILLUMINATED.}

\subsubsection{VERIFY Rotation Beacon is NOT ILLUMINATED.}
5.5.174.2 Message View Display VTP-UI-2207A (10cated at Alarm Cabinet Swing Out Panel) CLEARS alarm message.

5.5.175 POSITION Circuit Breaker \#3 (located at Mini Power Zone Cabinet VTP-PNL-2204A) to OFF.

5.5.176 POSITION Glycol Pump Control Switch VTP-HS-2210A to OFF (located on door of Exhauster Control Cabinet VTP-PNL-2205A).

5.5.177 DISCONNECT Thermocouple Simulator to the terminals wires located in thermowe11 junction VTP-TE-2222A

5.5.178 RECONNECT Thermocouple to the terminals located in thermowell junction VTP-TE-2222A.

\begin{tabular}{|r|r|r|r|}
\hline Document No. & Rev/Mod & Page \\
& OTP-060-001 & & \\
& & 1 & 66 \\
\hline
\end{tabular}


HNF.

WHC-SD-WM-OTR-226 Revision 0

DfC 515 PT

\subsection{INTERLOCK/ALARM CHECK (Cont.)}

5.5.179 Test Director SHALL VERIFY that section 5.5 is COMPLETE by SIGNING below.

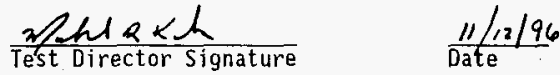

5.5.180 Quality Control Inspector SHALL VERIFY that section 5.5 is COMPLETE by SIGNING below.

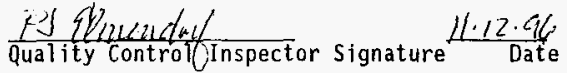

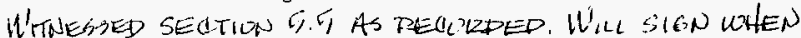

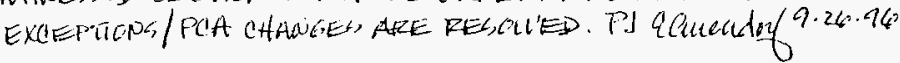

Document No.

Rev/Mod

Page

OTP-060-001

1 
HNF.

WHC-SD-WM-OTR-226 Revision 0

D. 515797

\subsection{SYSTEM ISOLATION}

5.6.1 VERIFY/POSITION panel MCC-Al, disconnect B-2 (A-10) PICS and

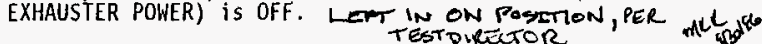

5.6.2 VERIFY/POSITION Main 480V Disconnect Switch VTP-CKT-2201A is in the OFF position.

5.6.3 VERIFY/POSITION Exhauster Fan Motor 480V Disconnect Switch VTP-DS-2212A EXH FAN DR UNIT VFD-2212A PWR is in the OFF position.

5.6.4 VERIFY/POSITION Glycol Heater 480V Disconnect Switch VTP-DS-2213A FILTER TRAIN GLY HEATER PWR is in the OFF position.

5.6.5 VERIFY/POSITION Mini Power Zone 480V primary Circuit Breaker VTP-CKT-2210A (located in Cabinet VTP-PNL-2204A, DP-2204A MINI POWER ZONE) is OFF.

5.6.6 VERIFY/POSITION Mini Power Zone 240V secondary Circuit Breaker

VTP-CKT-2211A (located at Cabinet VTP-PNL-2204A) is OFF.

1

Page 
HNF-

WHC-SD-WM-OTR-226 Revision 0

Do 5.15 .97

\subsection{SYSTEM ISOLATION (Cont.)}

5.6.7 VERIFY/POSITION the following $120 \mathrm{~V}$ circuit breakers (located at Cabinet VTP-PNL-2204A) are OFF:

- Circuit Breaker \# 1 (Enclosure Heaters and Fans)

- Circuit Breaker \#2 (Flammable Gas Monitor)

- Circuit Breaker \#3 (PLC power)

- Circuit Breaker \#4 (Heat Trace)

- Circuit Breaker \#5 (Convenience Receptacle)

- Circuit Breaker \#6 (PLC control circuit, Module 8)

- Circuit Breaker \#7 (PLC control circuit, Module 9)<smiles>C1C2CC12</smiles><smiles>C1C2CC12</smiles>

- Circujt Breaker \#8 (spare)

5.6.8 VERIFY/POSITION Fan Control Selector Switch VTP-HS-2212A (located on door of EXHAUSTER CONTROL CABINET VTP-PNL-2205A) is in off position.

5.6.9 VERIFY/POSITION G1ycol Pump Control Switch VTP-HS-2210A (located on door of EXHAUSTER CONTROL CABINET VTP-PNL-2205A) is in OFF position.

\begin{tabular}{|c|c|c|}
\hline \begin{tabular}{c|c|c|} 
Document No. \\
OTP-060-001
\end{tabular} & $\begin{array}{c}\text { Pev/Mod } \\
1\end{array}$ & 69 \\
\hline
\end{tabular}


HNF

\subsection{SYSTEM ISOLATION (Cont.)}

5.6.10 VERIFY/POSITION CAB HEAT/COOL Selector Switch VTP-HS-2213A (located on door of EXHAUSTER CONTROL CABINET VTP-PNL-2205A) is in ofF position.

5.6.11 CLOSE Filter train Inlet valve VTP-V-2250A.

5.6.12 CLOSE Filter train outlet valve VTP-V-2251A.

* 5.6.13 LoCK AND TAG the Main 480V Disconnect Switch VTP-CKT-2201A.

5.6.14 REMOVE Intet test section-of the Portable-Exhauster,

5.6.15 Test Director SHALL VERIFY that section 5.6 is COMPLETE by SIGNING below.

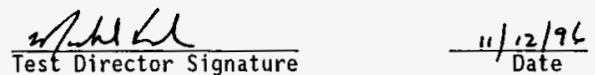

5.6.16 Quality Control Inspector SHALL VERIFY that section 5.6 is COMPLETE by SIGNING below.

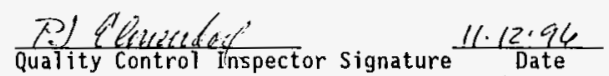

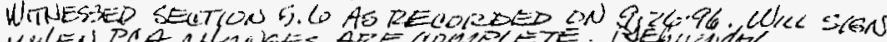

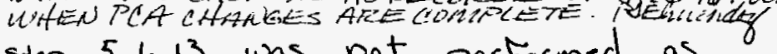

* note: step 5.6 .13 was not performed as

the exhauster required power for freeze protection. Breakers were closed to power neaters. 2/be cical $1 / 2 / 96$

\begin{tabular}{|r|r|r|}
\hline Document Ho. & Rev/Mod & Page \\
OTP-060-001 & 1 & 70 \\
\hline
\end{tabular}




\section{DATA SHEET 1 - LEAKAGE RATE CALCULATION}

(This page may be reproduced as necessary)
DATE: $9 / 30 / 96$
TEST \#: 1 (PRESSURE)

\begin{tabular}{|c|c|c|}
\hline & INITIAL & FINAL: \\
\hline Time & $t i=1345$ & $t f=1400$ \\
\hline Pressure (psig) & $\begin{aligned} \mathbf{P i} & =\frac{12.0}{\text { inches Water }} \begin{array}{l}\text { Column } / 27.7 \\
\end{array} \\
& =.433\end{aligned}$ & $\begin{aligned} \text { Pf } & =\frac{10.0}{\text { Column/ } 27.7} \text { inches Water } \\
& =.362 .\end{aligned}$ \\
\hline Barometric pr (psi) & $\begin{aligned} \mathrm{Bpi} & =29.42(\mathrm{IN} \mathrm{Hg})(0.491) \\
& = \\
& +4.514 .445 \mathrm{mLL} \text {. }\end{aligned}$ & $\begin{aligned} & \mathrm{BPf}=29.42(\mathrm{IN} \\
&\mathrm{Hg})(0.491)\end{aligned}$ \\
\hline Duct pr (psfa) & $\begin{aligned} & D P i=(P i+B p i)(144) \\
&=-2150 \cdot 4+2142 \cdot 432 \\
&\end{aligned}$ & 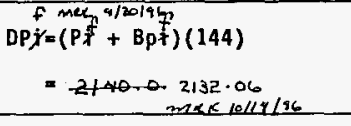 \\
\hline Temperature $\left({ }^{\circ} R\right)$ & $\begin{aligned} T i & =\underbrace{62.4} \cdot F+460 \\
& =522.4\end{aligned}$ & $\begin{aligned} T f & =\underline{62.8}^{\circ} F+460 \\
& =522.8\end{aligned}$ \\
\hline
\end{tabular}

Test Volume: $\quad V=\underline{61.8}$ cubic feet

Gas constant: $R=53.35 \mathrm{ft}-1 \mathrm{~b} /(1 \mathrm{~b} *$ deg $R)$

Test Duration: $\Delta t=(t f-t i)=15$ minutes

$Q=(D P i / T i-D P f / T f) V /(R \times \Delta t \times 0.075)=.024$

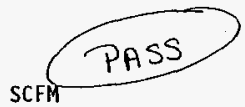

$Q$ is the Average total leak rate per ASME N510-1989, Section 6.5.3.9, in standard $\mathrm{ft}^{3} / \mathrm{min}$ (SCFM) ice sol/4/46

L Allowable Leak Rate $=-5.3 \quad$ SCFM per cog engineer jirection $9 / 30 / 96$
Whol $R+$ rel
Test Director Signature
$\frac{10 / 14 / 96}{\text { Date }}$
[Owen Nelson determined .3scFm criteria]

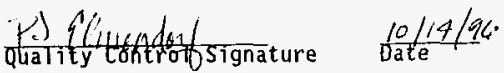

\begin{tabular}{|c|c|c|}
\hline $\begin{array}{c}\text { Document Ho. } \\
\text { OTP-060-001 }\end{array}$ & Rev/Mod & Page \\
& & 1
\end{tabular}


HNF.

WHE-SD-WM-OTR-226 Revision 0

\section{DATA SHEET 2 - LEAKAGE RATE CALCULATION}

(This page may be reproduced as necessary)
DATE: $9 / 30 / 96$
TEST \#: 1 (vacuUm)

\begin{tabular}{|c|c|c|}
\hline & INITIAL & FINAL \\
\hline Time & $t i=1423$ & $t f=1438$ \\
\hline Pressure (psig) & $\begin{aligned} P i & =-12 \quad \begin{array}{l}\text { inches Water } \\
\text { Column/ } 27.7\end{array} \\
& =-.433\end{aligned}$ & $\begin{aligned} \text { Pf } & =\frac{-9.2}{\text { Column/ } 27.7} \text { inches Water } \\
& =-.332\end{aligned}$ \\
\hline Barometric pr (psi) & $\begin{aligned} B p i & =29.42(I N \mathrm{Hg})(0.491) \\
& =+4.45=14.445 \\
& \text { max } 10 / 14 / 96\end{aligned}$ & $\begin{aligned} & B P f=29.40 \quad(I N \\
&\mathrm{Hg})(0.491) \\
&=+4.43 \quad 14.435 \\
&\end{aligned}$ \\
\hline Duct pr (psfa) & $\begin{aligned} D P i & =(P \mathbf{i}+B p i)(144) \\
& =2,0+8+4 \begin{array}{c}2017.728 \\
m R x .0 / 441 / 6\end{array}\end{aligned}$ & $\begin{array}{l}D P X=(P \dot{A} f+B p f)(144) \\
=2,030.832\end{array}$ \\
\hline Temperature ( $\left.{ }^{\circ} R\right)$ & $\begin{aligned} T i & =64.3{ }^{\circ} \mathrm{F}+460 \\
& =524.3\end{aligned}$ & $\begin{aligned} \text { Tf } & =65.7 \\
& =525.7\end{aligned}$ \\
\hline
\end{tabular}

Test Volume: $\quad V=61.8$ cubic feet

Gas constant: $R=53.35 \mathrm{ft}-1 \mathrm{~b} /(1 \mathrm{~b} *$ deg $R)$

Test Duration: $\Delta t=(t f-t i)=15$ minutes

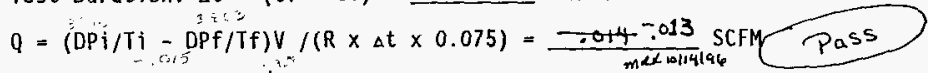

$Q$ is the Average total leak rate per ASME N510-1989, Section 6.5.3.9, in standard $\mathrm{ft}^{3} / \mathrm{min}$ (SCFM).

$L_{s}=$ Allowable Leak Rate $=.-3$ SCFM per cog engineer direction $9130 / 96$

MhalRLh

Test Director Signature Date

[owen Netison estakliahed -.3 criterie]

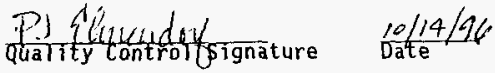

Document NO.

OTP-060-001

Rev/Mod

1

Page 


\section{OPERATIONAL TEST PROCEDURE EXCEPTION LOG}

This page may be reproduced as necessary

$$
\text { PAGE } 1 \text { of } 1
$$

\begin{tabular}{|c|c|c|}
\hline \multicolumn{3}{|c|}{ Operational Test Procedure EXCEPTION LOG } \\
\hline Number & Date & Description \\
\hline 1 & $10 / 1 / 96$ & FILTER 1 DP HIHI ALARM ACKNOWLEDGEMENT \\
\hline 2 & $10 / 1 / 96$ & ALARM ACKNOWLEDGEMENT \\
\hline 3 & $10 / 1 / 96$ & FILTER IIL DPHIHI RLARM ACKNOWLEDGEMENT \\
\hline 4 & $1011 / 96$ & PLENUM DP UNDER ALARM \\
\hline 5 & $10 / 196$ & PREFILTER PRESSURE HI \\
\hline 6 & 101.196 & STACKFLOW LO akarm \\
\hline 7 & 101.196 & GLYCOL PUMP/HEATER H TST \\
\hline 8 & $10 / 1 / 94$ & GLYCOZ HEATER TEST \\
\hline & & \\
\hline & & \\
\hline & & \\
\hline & & \\
\hline & & \\
\hline & & \\
\hline & & \\
\hline & & \\
\hline
\end{tabular}


HNF

WHC-SD-WM-OTR-226 Revision 0

DS.15.77

\section{WORKING COPY}

OPERATIONAL TEST PROCEDURE EXCEPTION RECORD

This page may be reproduced as necessary.

Page $\perp$ of 2

\begin{tabular}{|c|c|}
\hline $\begin{array}{l}\text { Operational Test Procedure step number: } \\
5.5 .17 \text { THRONGH } 5.5 .28 \\
\end{array}$ & $\begin{array}{l}\text { Operational Test Procedure } \\
\text { Exception Log Number: } 1\end{array}$ \\
\hline \multicolumn{2}{|l|}{ Description of Exception: FAN SHUTDOWN } \\
\hline \multicolumn{2}{|c|}{ with FILTER 1 DP HEH. HIHI. STACKFLOW UNDER alarm waS } \\
\hline \multirow{2}{*}{\multicolumn{2}{|c|}{ 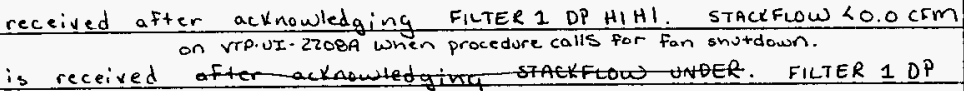 }} \\
\hline & \\
\hline \multirow{2}{*}{\multicolumn{2}{|c|}{$\begin{array}{l}\text { HIGH is received as pressure signal is lowered From HIHI } \\
\text { alarm. Procedure incorrectly specities pressure tolerance (5.5.25). }\end{array}$}} \\
\hline & \\
\hline \multicolumn{2}{|c|}{ Resolution of Exception: Correct procedure via PCA to acknowledge } \\
\hline \multicolumn{2}{|c|}{ individual alarms as they appear, exactly as they appear. } \\
\hline \multicolumn{2}{|c|}{ Note at beginning of section 5.5 directing Test Director to } \\
\hline \multicolumn{2}{|l|}{ reset message view several times } \\
\hline \multicolumn{2}{|l|}{ peA will correct to specifics. } \\
\hline \multicolumn{2}{|l|}{ pressure tolerance. } \\
\hline Date of Resolution: & $10 / 1 / 96$ \\
\hline Test Director signature: & rachalekel $10 / 14 / 96$ \\
\hline Cognizant Engineer signature: & Whal \\
\hline Quality Control signature: & P) $\{(2$, \\
\hline Tank Farim & \\
\hline
\end{tabular}

Document No.

OTP. $060-001$

$\mathrm{Rev} / \mathrm{Mod}$ 
HNF-

\section{OPERATIONAL TEST PROCEDURE EXCEPTION RECORD}

This page may be reproduced as necessary.

Page 2 of 2

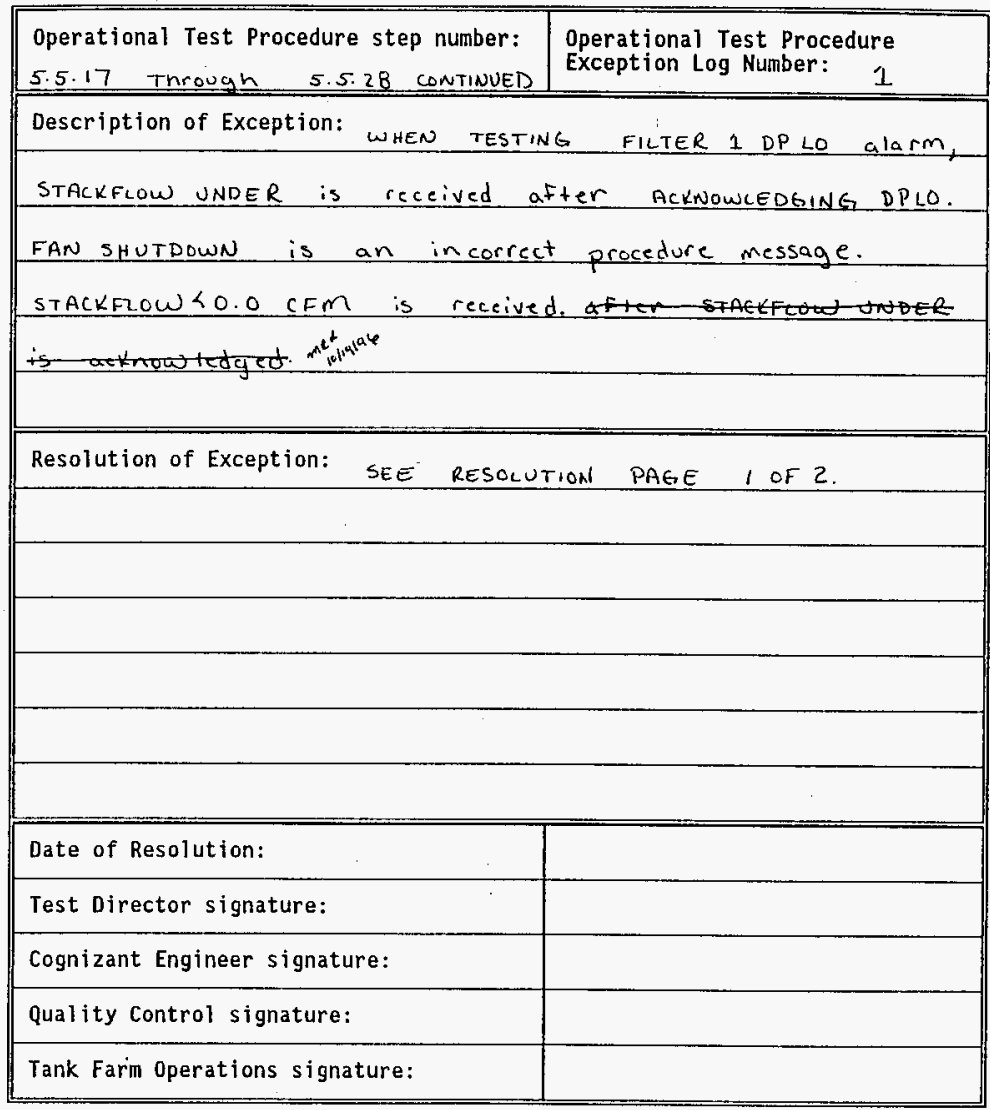

Document Ho.

OTP-060-001

Rev/Mod

Page 


\section{OPERATIONAL TEST PROCEDURE EXCEPTION RECORD}

This page may be reproduced as necessary.

Page -1 of 1

\begin{tabular}{|c|c|}
\hline Operational Test Procedure step number: & $\begin{array}{l}\text { Operational Test Procedure } \\
\text { Exception Log Number: } 2\end{array}$ \\
\hline
\end{tabular}

* GC concurance

gained From Janic EimendorF per telecon 1210196

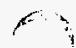

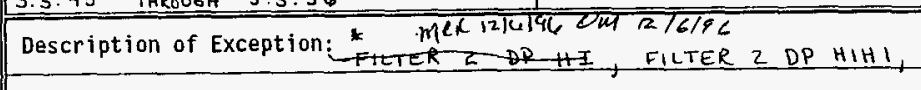

and FILTER 2 PP LO are each aceompanied by STACKFLOW UNDER alarms and STACKFLOWLO.O CFM alarms upon acunowledgement. In addition a FILTER 2 DP HI alarm is received and requires acknowledgement as pressure source STEPS 5.5.53, 5hutdown tack 15 sec; is brought down from HIHI alarm. Pressure tolerence is incorroc Resolution of Exception: correst procedure (OP) via PCA to acknowledge indixidual and subsequent alarms as they appear, exactly as they appear, rather than interpreting note at beginning of section 5.5 to acknowledge all a Jarms. Correct tolerence via PCA.

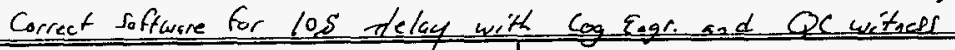
Date of Resolution:

Test Director signature:

Cognizant Engineer signature: Quality Control signature:

Tank Farm Operations signature: 1011196

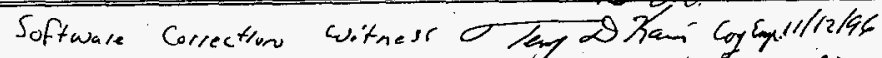

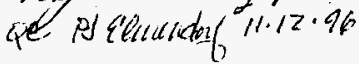

Dociment Wo.

OTP-060-001
Page 74 


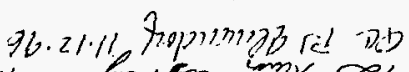

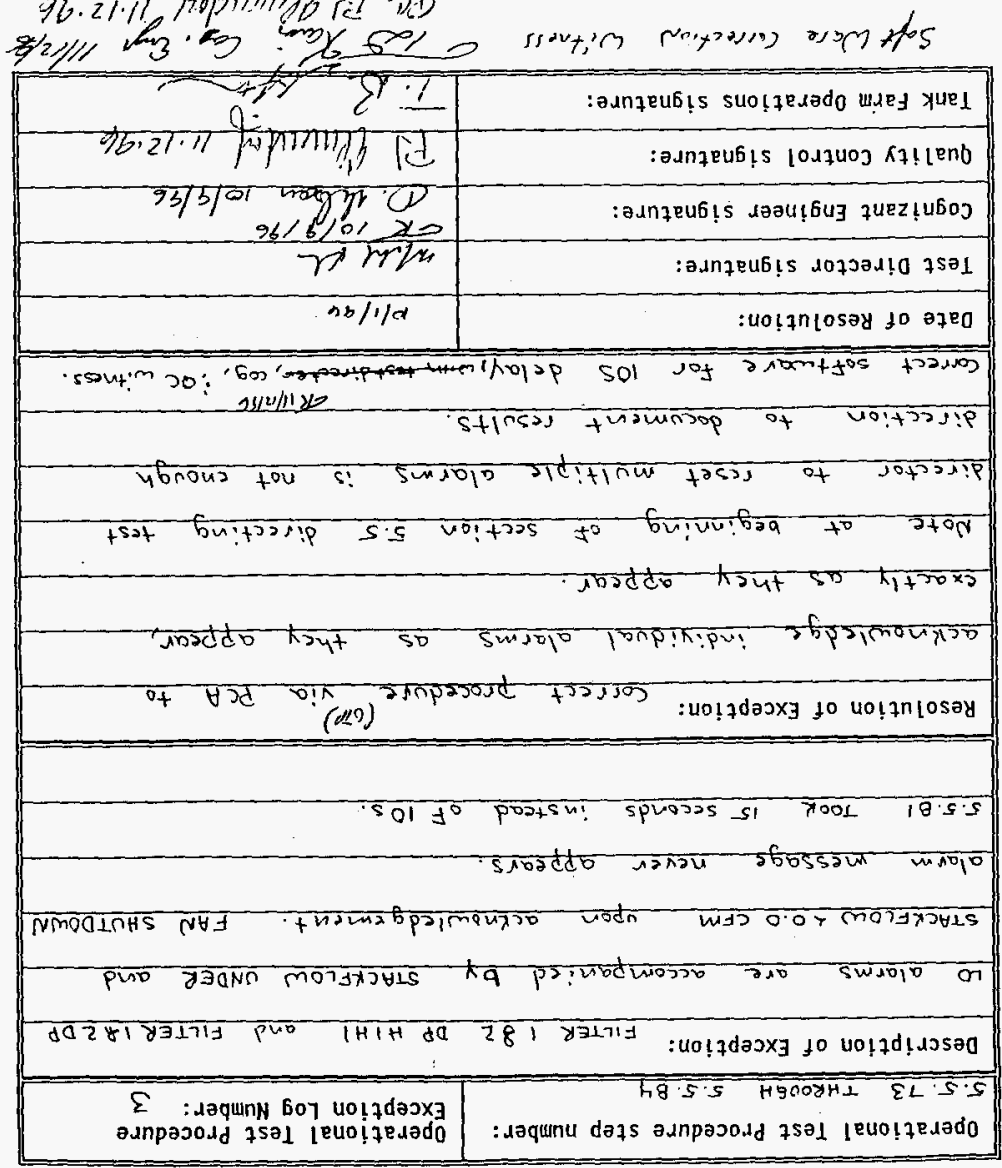

\footnotetext{
T to T abed

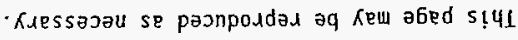

\section{a40ว}


ANF.

WHC-SD-WM-OTR-226 Revision 0

Doj 5.15 .97

OPERATIONAL TEST PROCEDURE EXCEPTION RECORD

This page may be reproduced as necessary.

Page 1 of 1

\begin{tabular}{||l|l||}
\hline $\begin{array}{l}\text { Operational Test Procedure step number: } \\
5.5 .103,5.5 .106,\end{array}$ & $\begin{array}{l}\text { Operational Test Procedure } \\
\text { Exception Log Number: }\end{array}$ \\
\hline Description of Exception: PLENUM DP UNDER alarm appears \\
\hline when procedure askS For PLENUM PRESSURE LO . \\
\hline \multicolumn{2}{|c|}{$\mid$} \\
\hline
\end{tabular}

Document No.

OTP-060-001

Rev/Mod

Page 


\section{OPERATIONAL TEST PROCEDURE EXCEPTION RECORD}

This page may be reproduced as necessary.

Page 1 of 1

\begin{tabular}{||l|l||}
\hline $\begin{array}{l}\text { Operational Test Procedure step number: } \\
5.5 .120\end{array}$ & $\begin{array}{l}\text { Operational Test Procedure } \\
\text { Exception Log Number: } 5\end{array}$ \\
\hline \begin{tabular}{l} 
Description of Exception: PREFILTER PRESSURE Hi alarm \\
\hline message is received while procedure incorractly
\end{tabular} \\
\hline calls For PLENUM PRESSURE LO.
\end{tabular}


NF.

WAFC-SD-WM-OTR-226 Revision 0

A-81

T) $\mathcal{H}_{5.15 .97}$

WORKING COPY

Printed ont Sep 24, 96, 9.11 an

OPERATIONAL TEST PROCEDURE EXCEPTION RECORD

This page may be reproduced as necessary.

Page 1 of 1

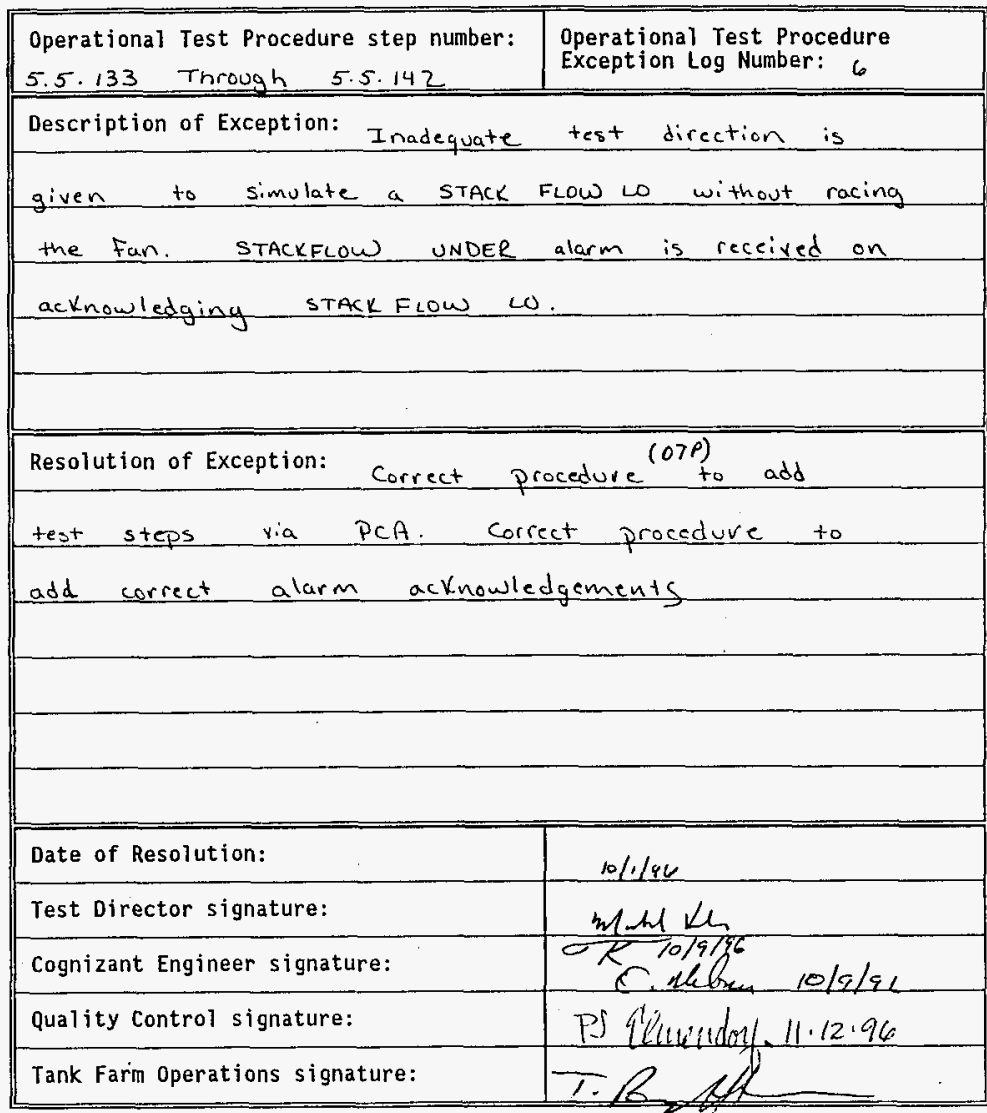

\begin{tabular}{|r|r|r|}
\hline \begin{tabular}{rr|r} 
Document No. \\
OTP-060-001/Mod
\end{tabular} & Page \\
& & 74 \\
\hline
\end{tabular}


HNF.

WHF-SD-WM-OTR-226 Revision 0

OPERATIONAL TEST PROCEDURE EXCEPTION RECORD

\. This page may be reproduced as necessary.

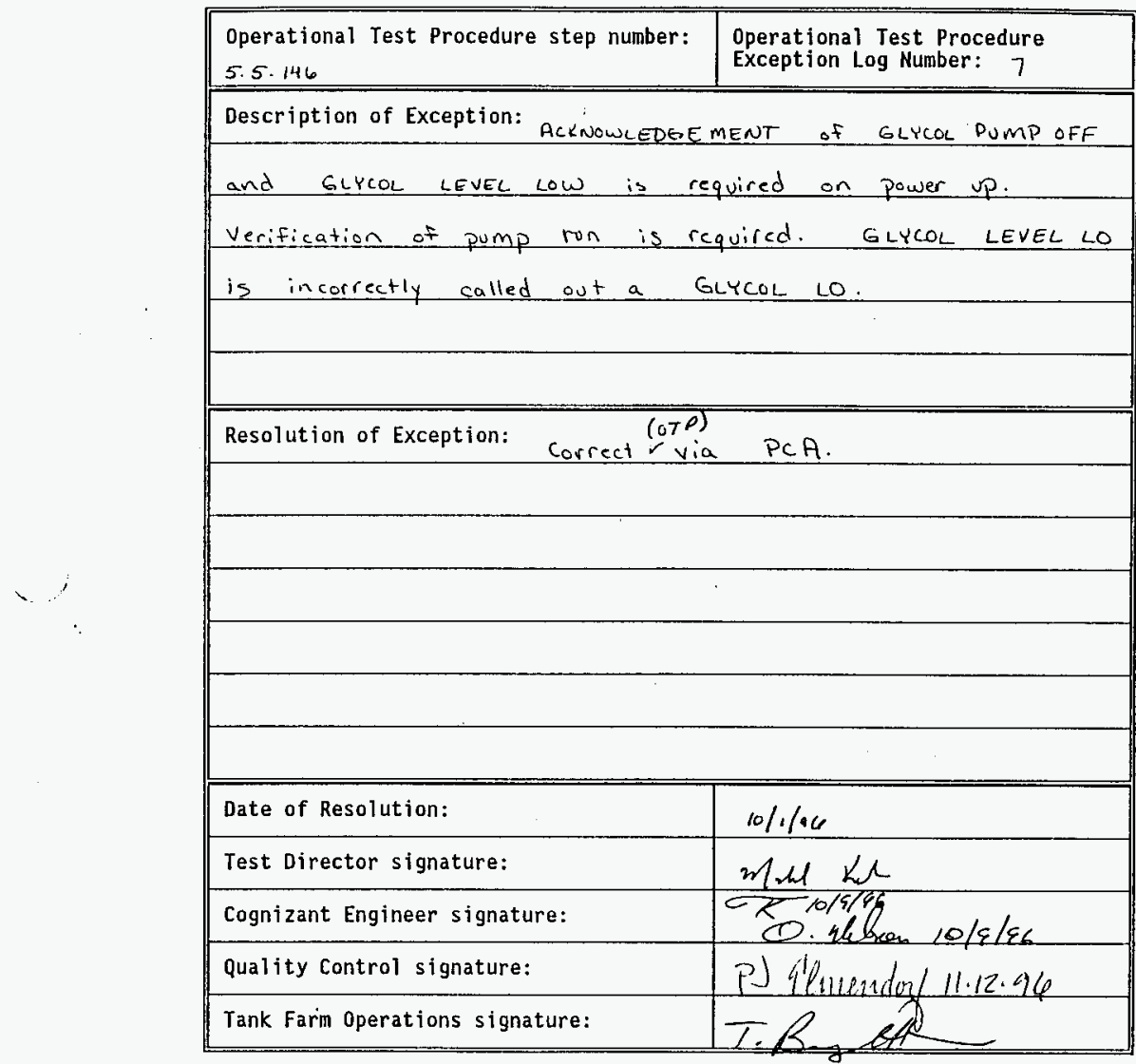

Page 1 of 1 
ANOF.

WHC-SD-WM-OTR-226 Revision 0

Dre.5.15.47

WORKING COPY

OPERATIONAL TEST PROCEDURE EXCEPTION RECORD

This page may be reproduced as necessary.

Page 1 of 1

Printed on. Sep $24,96,9211$ an:

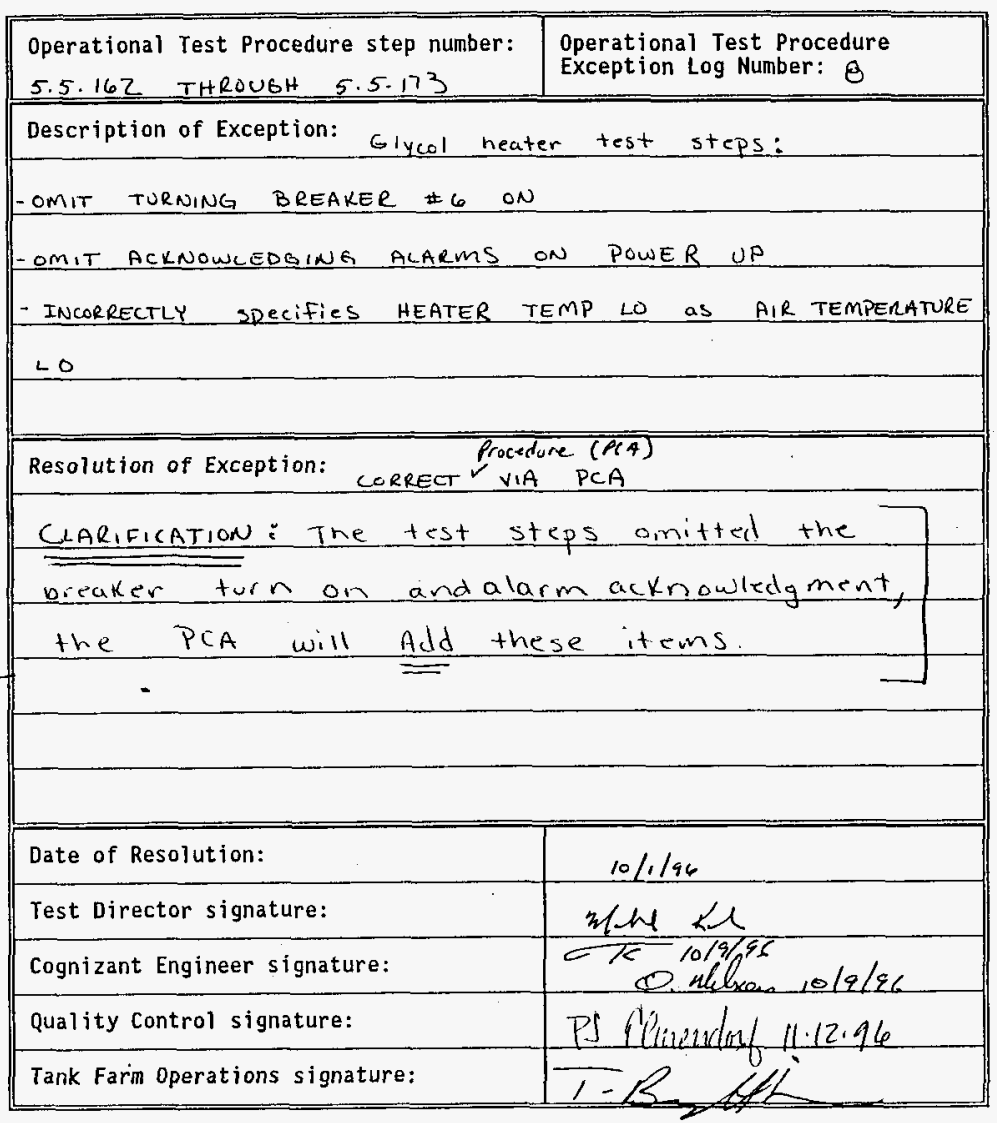

\begin{tabular}{|c|c|c|}
\hline $\begin{array}{l}\text { Docünent No. } \\
\text { OTP-060-001 }\end{array}$ & Rev/Mod & $\begin{array}{r}\text { Page } \\
\\
74\end{array}$ \\
\hline
\end{tabular}




\section{OPERATIONAL TEST PROCEDURE EXCEPTION RECORD}

This page may be reproduced as necessary.

Page of

\section{Operational Test Procedure step number:}

Operational Test Procedure Exception Log Number:

Description of Exception:

Resolution of Exception:

Date of Resolution:

Test Director signature:

Cognizant Engineer signature:

Quality Control signature:

Tank Farm Operations signature:

Document No:

OTP-060-001

Rev/Mod

Page 


\section{OPERATIONAL TEST PROCEDURE ACCEPTANCE RECORD}

This Operational Test Procedure has been completed and the results, including Procedure Change Authorizations, exceptions, and exception resolutions, have been reviewed for compliance with the intent of the Purpose (Section 1.0). The operational Test Procedure results are accepted by the undersigned:

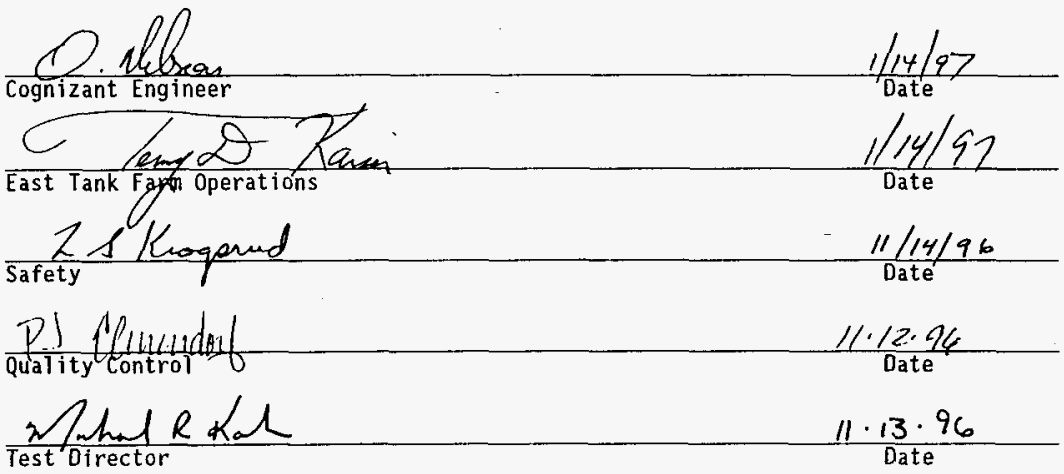

\begin{tabular}{l|l} 
Page \\
1
\end{tabular}




\begin{tabular}{|r|r|c|}
\hline $9 L$ & $L$ & 1 \\
ebed & pow/ray & $L 0-090-d 10$ \\
\hline
\end{tabular}

\begin{tabular}{|c|c|c|c|}
\hline & $\overline{\overline{96} / \overline{9} \overline{16}}$ & गच्वन्य गण & 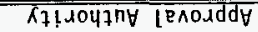 \\
\hline & $\overline{96 / 91 / 6}$ & pपoukey $\bar{g} \cdot \bar{g}$ & мa!ıay әכue \\
\hline & $\overline{96 / 01 / 6}$ & 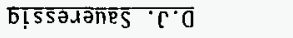 & $d \perp f \perp M /$ UeW $7 \supset \forall$ qe $7 S$ \\
\hline & $\overline{96 / 01 / 6}$ & 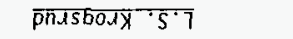 & KFafeS ONN $1 \mathrm{JM}$ \\
\hline & $\overline{96 /[1 / 6}$ & पеप्राण $\% 1$ & $\forall 0$ \\
\hline & $\overline{96 / 0 \mathrm{I} / 6}$ & $\overline{40746 ! 18} \cdot{ }^{\circ} 1$ & OdN \\
\hline & $\overline{96 /[I / 6}$ & 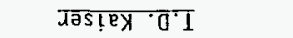 & 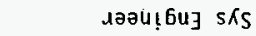 \\
\hline & 3LV0 & 31693130 & 980/NOILISOd \\
\hline $\begin{array}{r}\text { Y0IVN9ISJa } \\
\text { MAINJY }\end{array}$ & $\exists Y N \forall H J \pm 0 \quad \exists d \lambda L$ & $0 \cdot 100-090-\mathrm{d} 10 \mathrm{l} 10 \mathrm{f}$ & saunzeu6!s aunpasold \\
\hline$\overline{\mathrm{OS}}$ & MEN & & :pazejoddosuI ४Jd \\
\hline
\end{tabular}

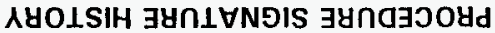

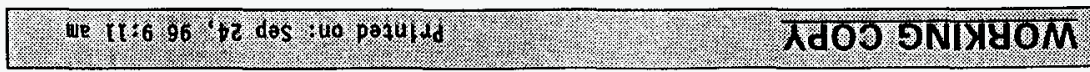

$98-\mathrm{V}$ 


\section{DISTRIBUTION SHEET}

\begin{tabular}{|c|c|c|c|c|c|}
\hline \multirow{2}{*}{$\begin{array}{l}\text { To } \\
\text { Distribution }\end{array}$} & \multirow{2}{*}{\multicolumn{3}{|c|}{$\begin{array}{l}\text { From } \\
\text { OD Nelson }\end{array}$}} & \multicolumn{2}{|c|}{ Page 1 of 1} \\
\hline & & & & \multicolumn{2}{|c|}{ Date $11 / 21 / 96$} \\
\hline \multirow{2}{*}{\multicolumn{4}{|c|}{$\begin{array}{l}\text { Project Title/Work Order } \\
\text { WNF-SD-WM-0TR-226, REV 0, Operational Test Report, } 500 \mathrm{cfm} \\
\text { Portable Exhauster. }\end{array}$}} & \multicolumn{2}{|c|}{ EDT No. 613043} \\
\hline & & & & \multicolumn{2}{|c|}{ ECN No. N/A } \\
\hline Name & MSIN & $\begin{array}{l}\text { Text } \\
\text { With All } \\
\text { Attach. }\end{array}$ & Text Only & $\begin{array}{l}\text { Attach.l } \\
\text { Appendix } \\
\text { Only }\end{array}$ & $\begin{array}{c}\text { EDT/ECN } \\
\text { Only }\end{array}$ \\
\hline $\begin{array}{l}\text { D. W. Crass } \\
\text { T. D. Kaiser } \\
\text { J. R. Kriskovich } \\
\text { L. S. Krogsrud } \\
\text { G. D. Johnson } \\
\text { W. H. Meader } \\
\text { O. D. Nelson } \\
\text { G. E. Rensink } \\
\text { D. J. Saueressig } \\
\text { E. M. Veith } \\
\text { T. J. Volkman }\end{array}$ & $\begin{array}{l}\text { H5-68 } \\
\text { T4-07 } \\
\text { R1-56 } \\
\text { T4-07 } \\
\text { S7-14 } \\
\text { S8-05 } \\
\text { S2-24 } \\
\text { S2-24 } \\
\text { S8-05 } \\
\text { H5-68 } \\
\text { T4-07 }\end{array}$ & $\begin{array}{l}x \\
X \\
X \\
x \\
X \\
X \\
X \\
X \\
X \\
X \\
X\end{array}$ & & & \\
\hline
\end{tabular}

